\title{
Organizational Black Hole Theory
}

Farajollah Rahnavard Associate Professor, Department of Management, Institute for Management and Planning Studies, Tehran, Iran.

\begin{abstract}
There are issues in organizations that require new theoretical formulation. Hence, metaphorical theorizing is used in the study of organizations to interpret them and understand their complexities. In this method, the organization is likened to an entity and one of the key features of that entity is generalized to the organization. It should be borne in mind that most organizational theories are based on a positivist paradigm that focuses on knowledge and data in an attempt to discover the nomothetic of social systems. This article is an attempt to build a theory based on interpretive paradigm that puts the organizational black hole theory forward in a metaphorical way. The black hole theory of the organization has been adopted from the cosmic black hole metaphor. In the first step, the key features of the organizational black hole were summarized in accordance with the researcher's interpretation, taking into account the one-on-one correspondence and adopting the cosmic black hole characteristics. In the second step, the definition of the organizational black hole was presented based on key features, and in the third step the overall framework of the theory was formulated. In addition, by analyzing the characteristics of the organizational black hole theory, it was found that this theory falls under the interpretative paradigm. Finally, how one can test the theory in terms of falsifiability or utility is discussed.
\end{abstract}

Keywords: Organizational Black Hole, Theory Building, Metaphor, Positivist Paradigm, Interpretive Paradigm. 


\section{مقام}

آسيب، مفهومى است كه بهطور اجتنابنايذيرى با هر سازمانى يِيوند مىخورد. تعريف جهانشمولى از 》آسيب" برحسب سازمان وجود ندارد؛ در شكل اوليه، مفهوم آسيب نشانكر علم بيمارى است (Sroka \& Cygler, 2014). اصطلاح آسيبشناسى به علم شرايط بيمارى اشاره دارد، و در يك مفهوم گستردهر، ناظر بر عقب زرد يك يديده يا فعاليت است. آسيب سازمانى به عنوان حالتى از اخلال مهرم و طولانىمدت در عملكرد، و همجنين ناهنجارى در عمليات سازمانى دانى شناخته مى شود كه اثر تخريبى قوى بر كاركرد سازمانى دارد و مانع تحقق اهداف سازمانى مىشود. करें

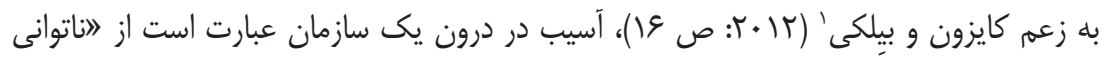
بلنسبت دائمى كه باعث ضايعات در معناى اقتصادى يا اخلاقى مىشود، و از حد تحمل اجتماعى فراتر مىرود. بنابراين، مىتوان كفت آسيب يعنى اخلال در درون يك سازمان يا يك زيرمجموعه

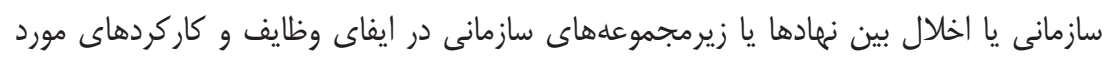

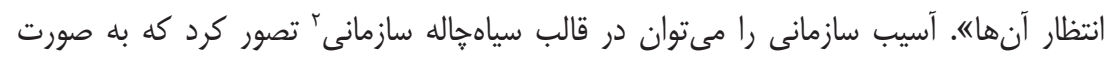
مستقيم قابل مشاهده نيست، اما وجود دارد و در نقش تخريبى تدريجى در سازمان ظاهر مىشود

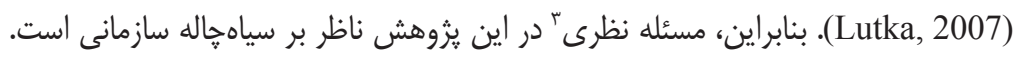

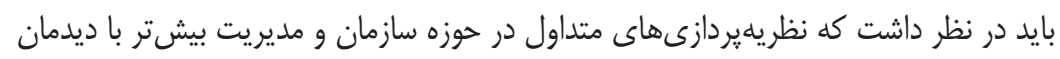
اثبات گرا صورت مى گيرد. اين ديدمان بر اين يِيشفرض استوار است كه سامانه اجتماعى همانند سامانه طبيعى است و با استفاده از روشهاى علوم طبيعى مىتوان قانونمندى حاكم بر اين

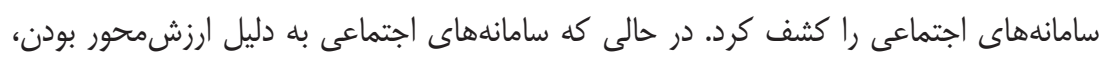

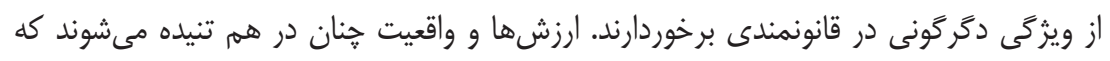
جدايى آنها كار مصنوعى است. بنابراين، دانش مديريت گونهاى از تفسير است. به سخن دئ ديخر،

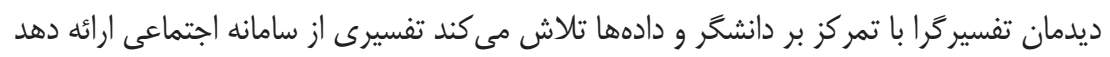

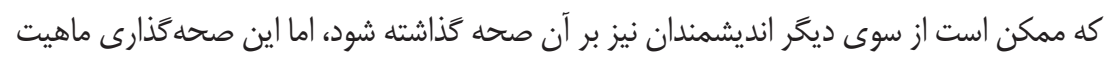
تفسيرى دانش را تغيير نمىدهد.

1. Kieżun \& Bielecki

2. Organizational Black Hole

3. Theoretical Problem 


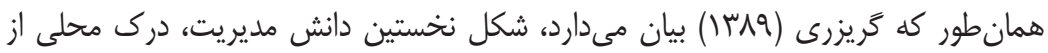
يك وضعيت خاص است و توسط انديشمندانى محقق مى شود كه مسئله سازمانى را حل مى كنند.

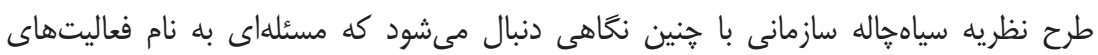
تخريبى در سازمان را به شيوهاى متفاوت از روش سنتى اثباتگرا تبيين كند. روش ساخت نظريه

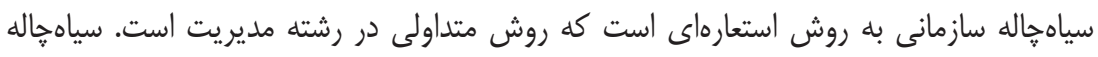

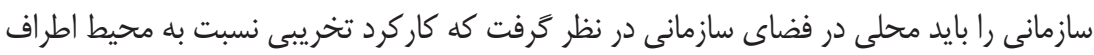

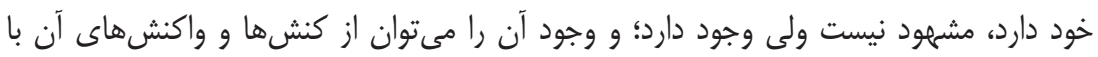

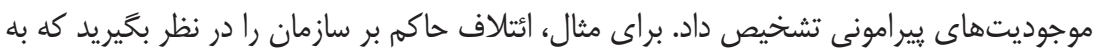

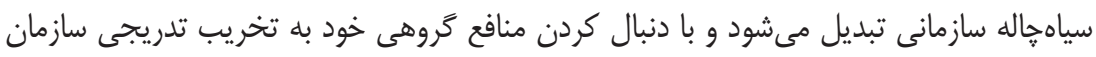

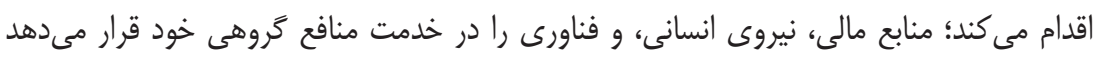

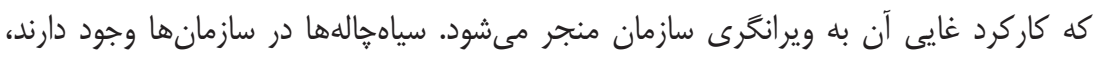

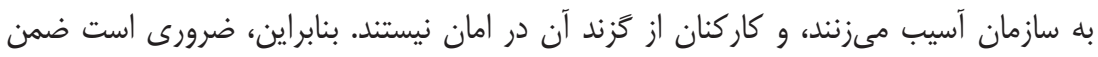

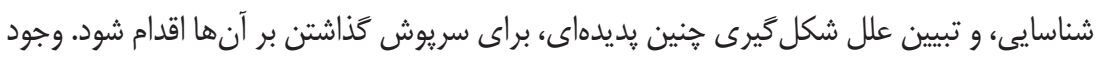

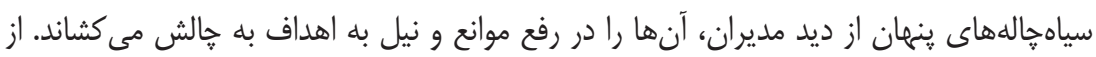

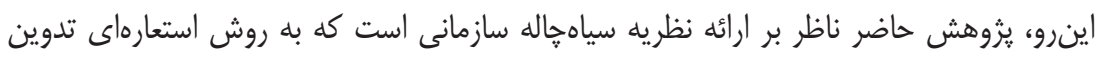

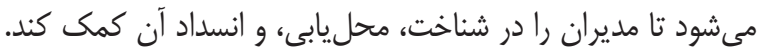

\section{مبانى نظرى يزووهش}

امروزه براى تبيين קديدههايى مانند فساد حاكميتى، تاراج سازمانى، انحطاط سازمانى، انزجار

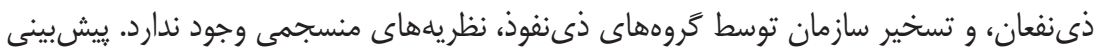

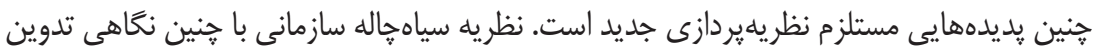

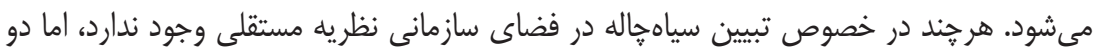

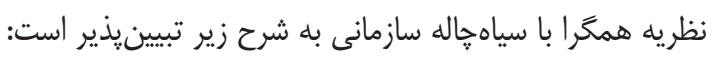

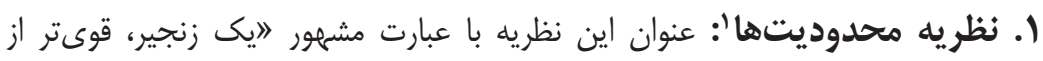

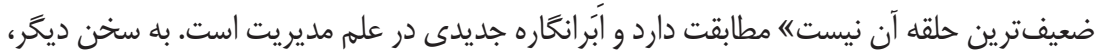

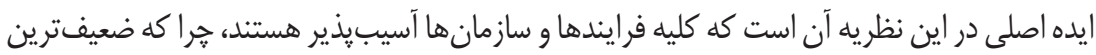

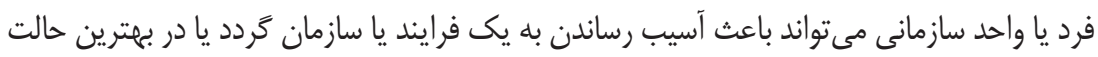

1. Theory of Constraints (TOC) 
باعث كاهش بهرهورى شود. ابتناى نظريه كلوكاه بر بهببود مستمر است و تمركز اصلى آن بر شناسايى محدوديتهاى توليدى با هدف بهبود مستمر ييامدهاى كل سازمان (Cox \& Schleier, 2010).

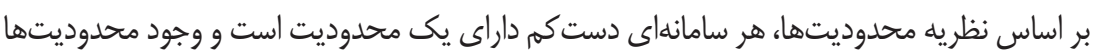
نشان دهنده قابليت بالقوه براى ييشرفت و انجام تغييرهاى نتيجهبخش است، بهَّونهاى كه محدوديتها

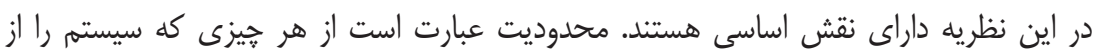
دسترسى به اهداف خود بازمىدارد (Goldratt, 2010). در سازمانهاى توليدى، محدوديت را با نام

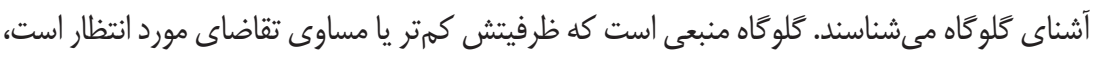

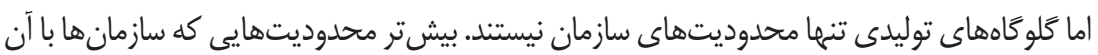

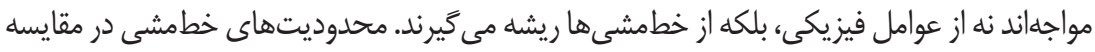

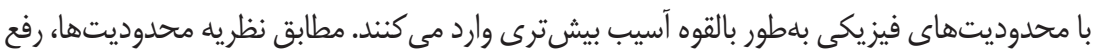
محدوديتها مستلزم ينج كام اساسى است (شكل ().
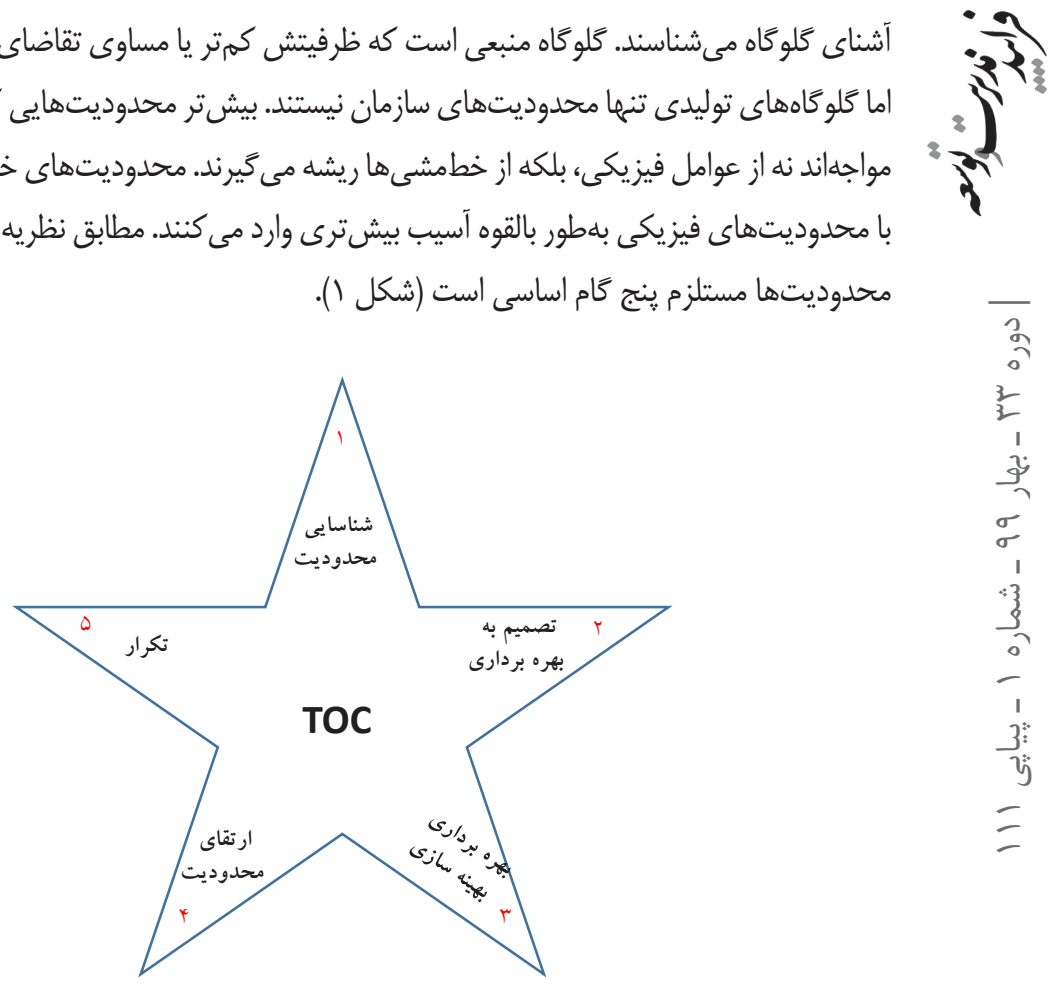

شكل ا: فرايند بهبود مستمر در نظريه محدوديتها

با در نظركَرفتن اين واقعيت كه اين نظريه تنها ناظر بر شناسايى گَلوكاهها و رفع آنها با رعايت كامهاى ينج كانه است، نمىتواند در تبيين بديده سياهُاله سازمانى كارساز باشد.

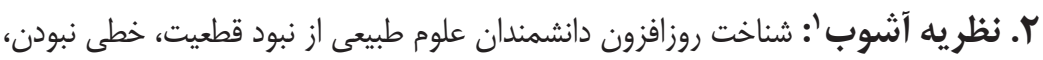


و ييشيينىنايذير بودن در قلمرو طبيعى، علاقه دانشمندان علوم اجتماعى را به اين اكتشافات جديد

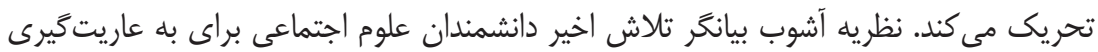

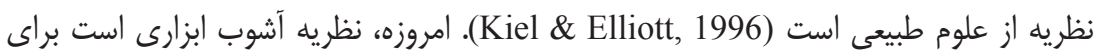

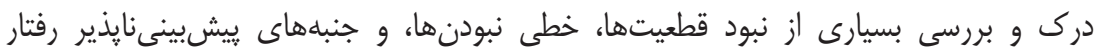

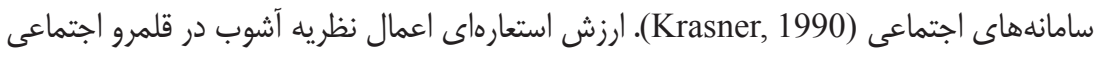

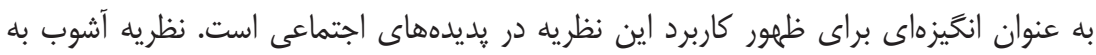

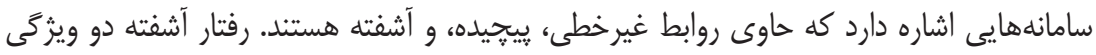

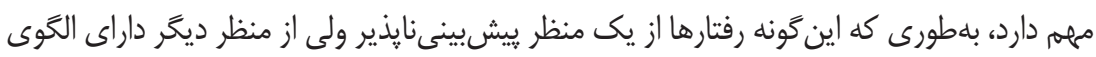

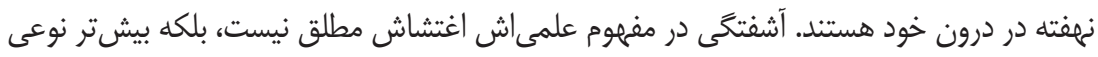

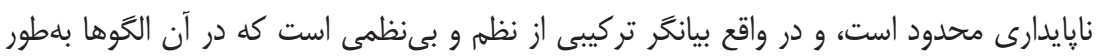

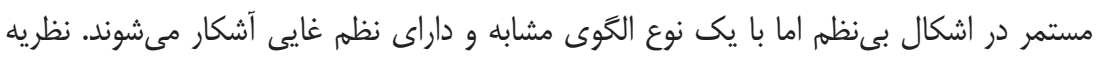

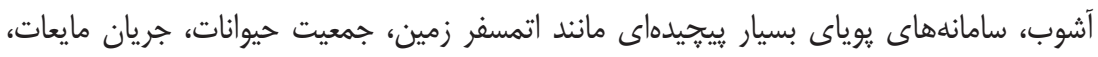

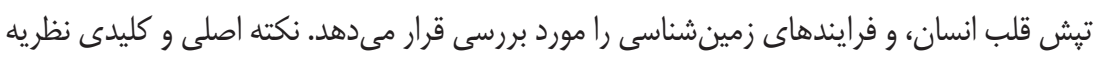

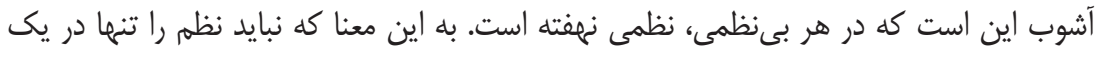

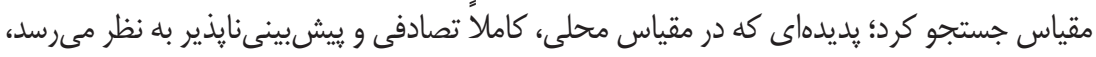

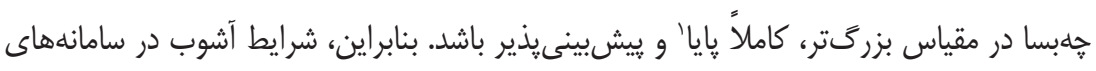

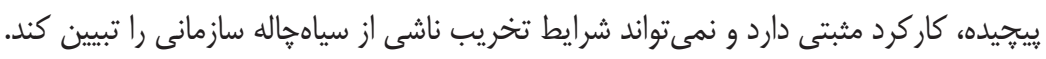

\section{ضرورت ساخت نظريه جديد}

اخر ظهور يديدهاى تخريبخر در سازمانها را در نظر بخيريم، اين يرسش مطرح مى قشود

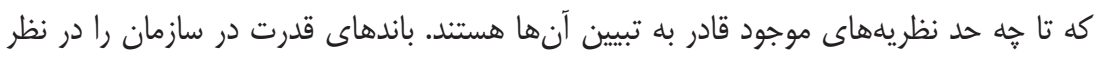

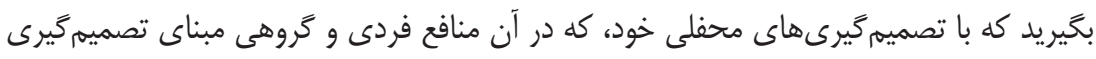

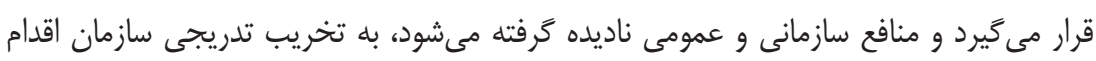

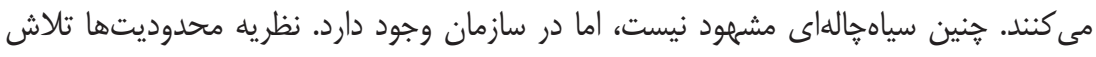

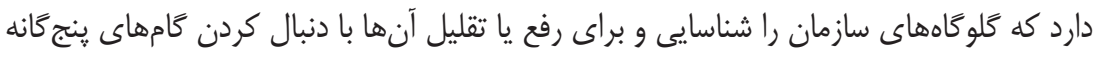

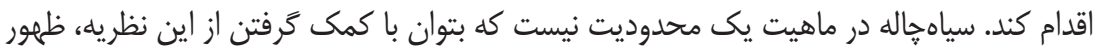

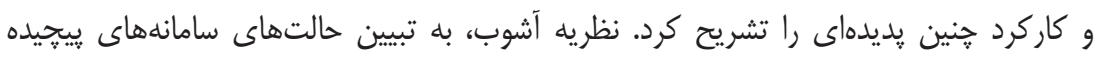

1. Stationary 
مىيردازد و براى حالت آشفتكى، نقش مثبتى را در نظر مى گيرد كه از طريق ظرفيتسازى به

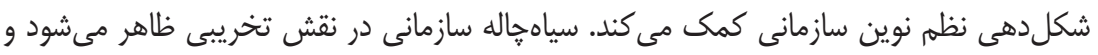

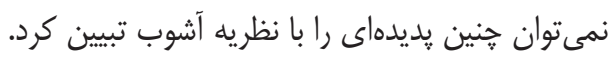
استعاره مثلث برمودا شايد يكى از ويثَى هاى سياهياله سازمانى را نشان دهد. مثلث بران برمودا

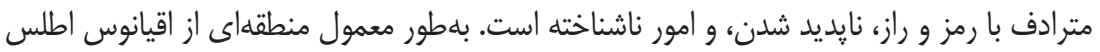
است كه در كرانه برمودا، نوك جنوبى فلوريدا و يورتوريكو واقع شده است. امثلث برموداه در زبان

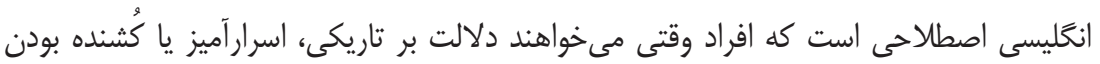

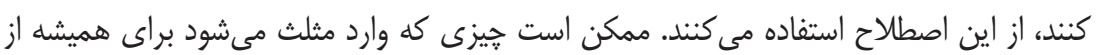

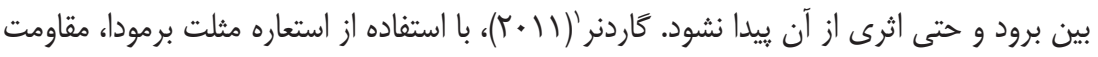

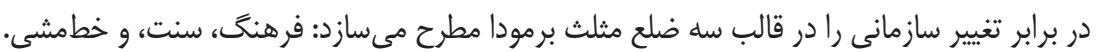
कर

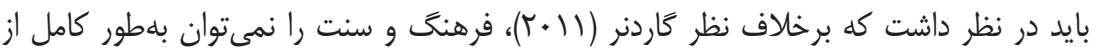
هم تفكيك كرد. به هر حال با فرض تفكيك، كاردنر (1) (1) معتقد است هر برنامة تغيير بايد اين

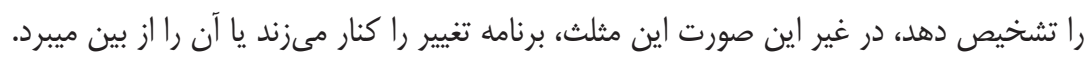

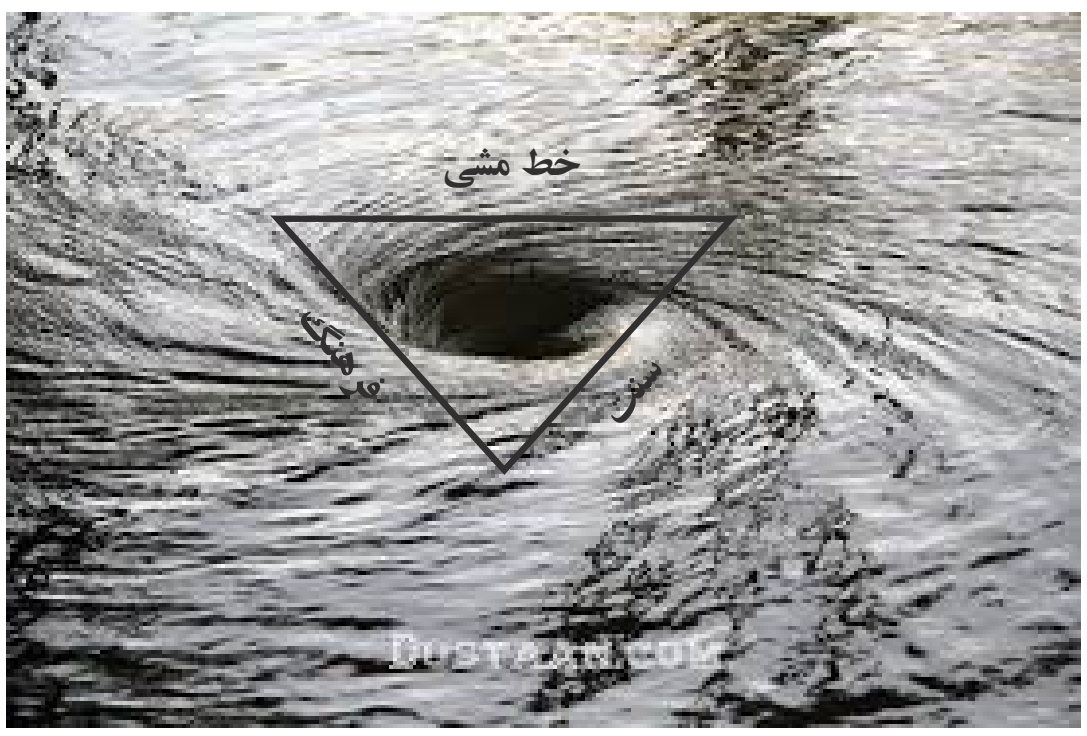

شكل r: مثلت برمودا به عنوان عامل بازدارنده در بهبود سازمانى

1. Gardner 
خطمشى، ضلع اول مثلث برمودا است. وقتى سازمانها براى مدتزمانى وجود دارند، بلطور معمول خطمشىهايى را براى كنترل تغيير يا رشد دنبال مى كنند. بسيارى از سازمانها از خطمشى مانى

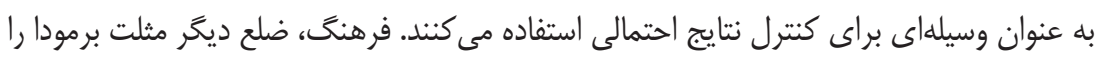
تشكيل مىدهد. فرهنگ بستر زندگى كارى هر فرد است. هرجند افراد ممكن است آن را متفاوت

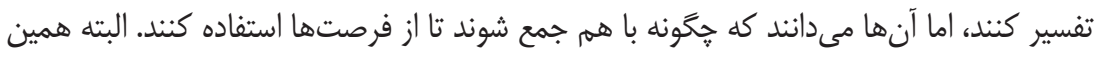
فرهنگ مىتواند در نقش بازدارنده و عامل از دست دادن فرصتهاى محيطى باشد. سرانجام،

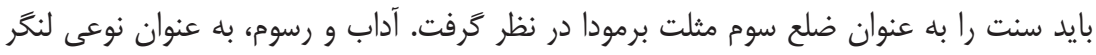

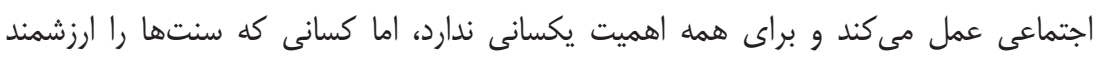

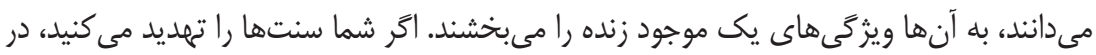

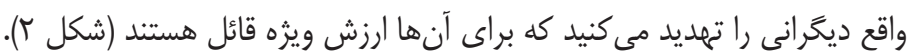

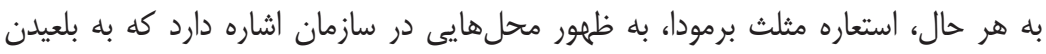

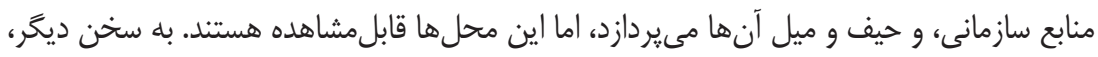

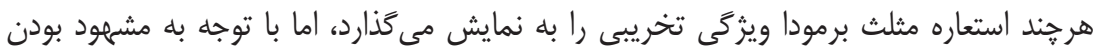

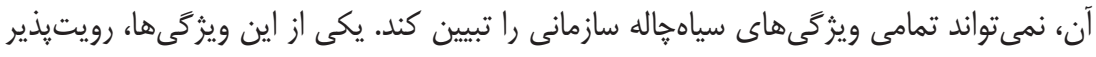

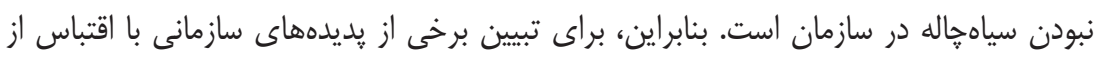
مفهوم سياه جاله كيهانى، مىتوان به ارائه نظريه جديد (نظريه سياه هاله سازمانى) اقدام كرد.

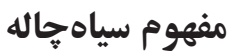

سياهجاله كيهانى عبارت است از جسمى كه كشش كرانشى آن به حدى است كه حتى نور

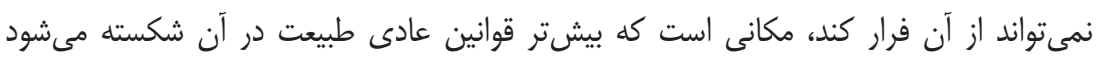

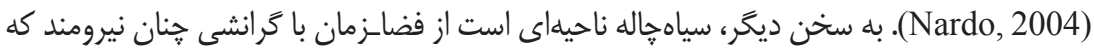

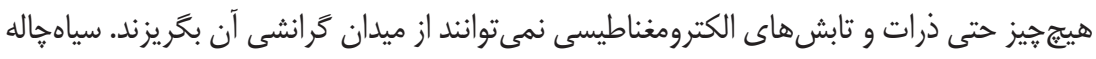

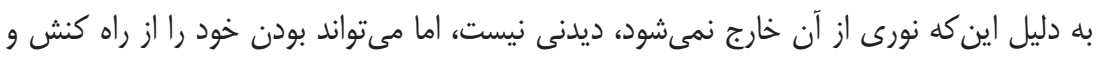
واكنش با ماده ييرامون خود نشان دهد (شكل بّام). 

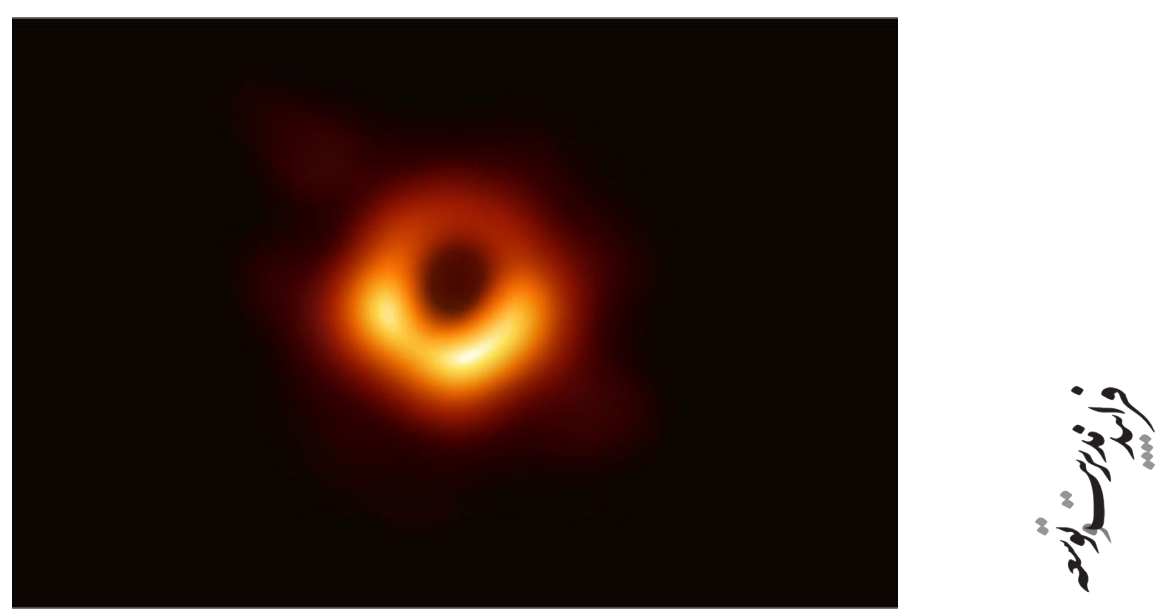

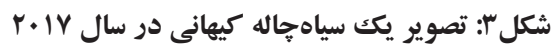

با استفاده از استعاره سياهجاله كيهانى، تلاش براى تعريف سياهجاله در سامانههاى اجتماعى

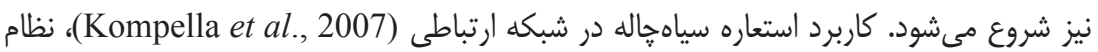

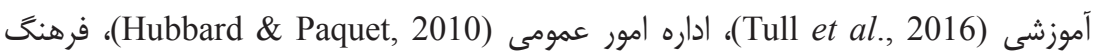

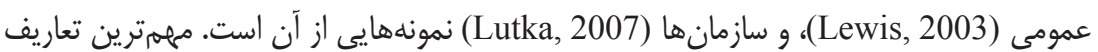
ارائهشه از سياه خاله در ادبيات علوم ادارى به شرح جدول (1) است.

جدول ا: تعريف سياهجاله از سوى انديشمندان علوم ادارى

\begin{tabular}{|c|c|c|}
\hline تعريف & منبع & رديف \\
\hline 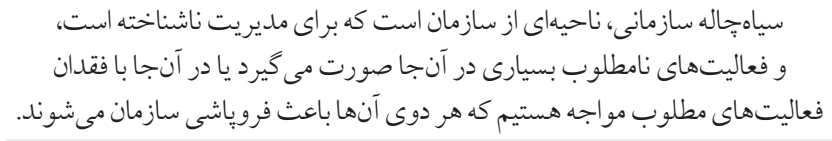 & 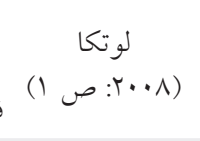 & 1 \\
\hline 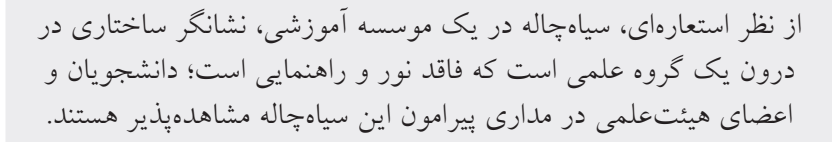 & 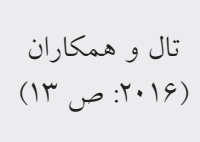 & r \\
\hline 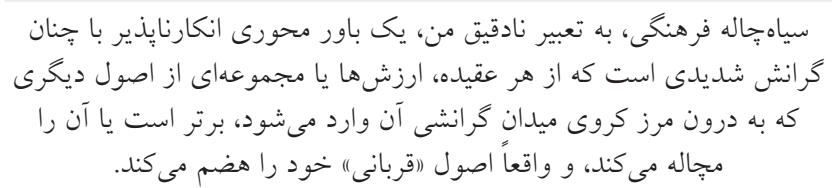 & 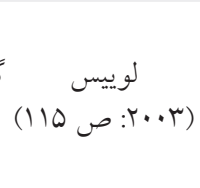 & $r$ \\
\hline
\end{tabular}


با توجه به مفاهيم يِيَّفته، مىتوان كفت كه تعاريف ارائهشه از سياهجاله در سامانههاى

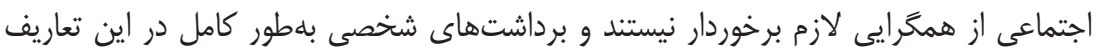

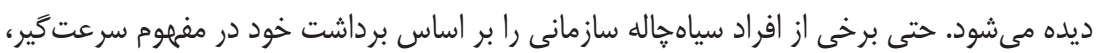

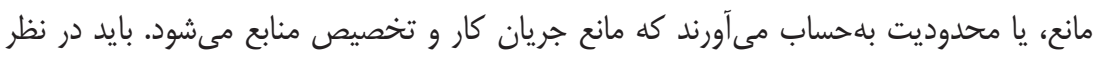

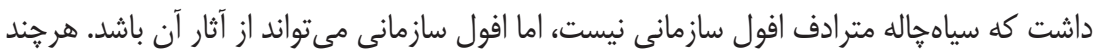

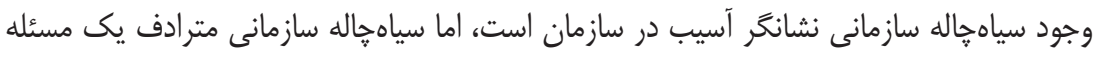

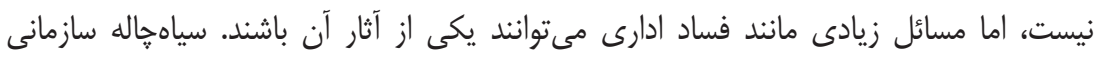

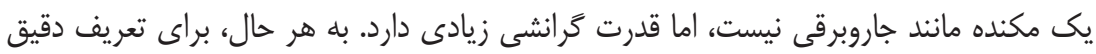

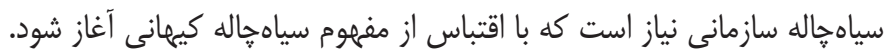

\section{كاربرد سياهجاله در سامانههاى اجتماعى}

در سال هاى گذشته، استعاره سياهخاله در سامانهاى اجتماعى به شرح زير بكار گَرفته مىشود:

\section{سياهجاله در موسسه آموزش عالى}

به زعم تول و همكاران (ع +(T)، يك دانشكده مهندسى معمول را مىتوان به مثابه يك

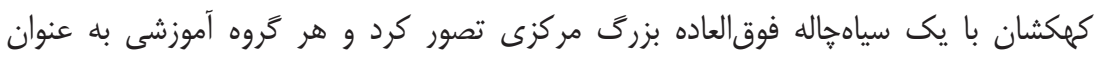

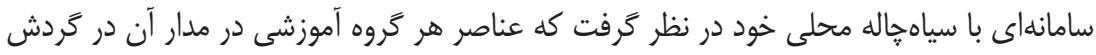

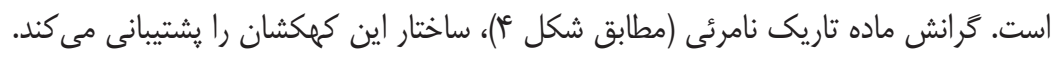




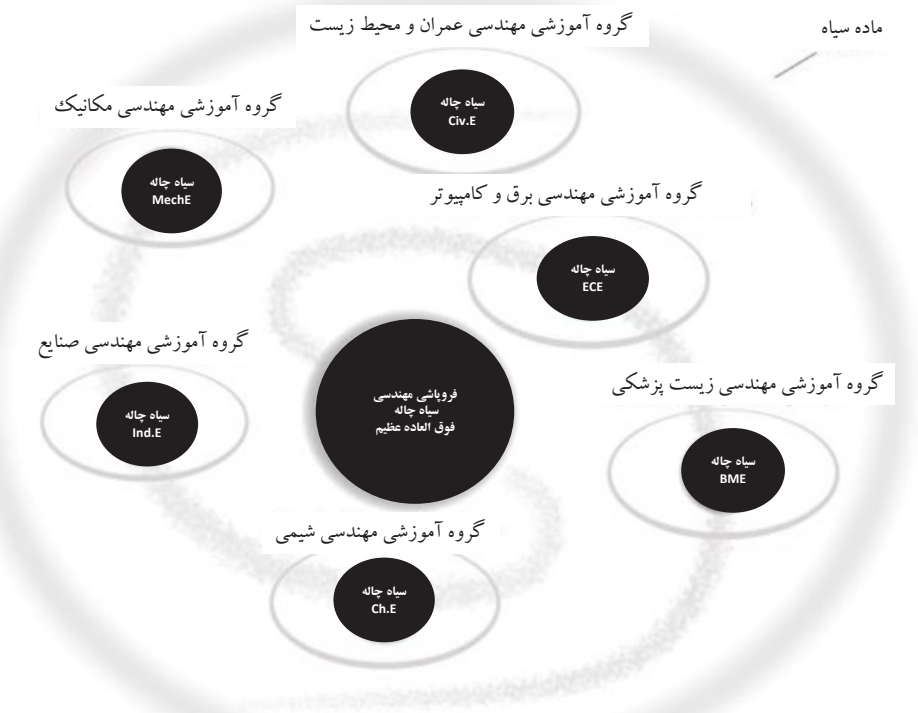

شكل fا: دانشكده مهندسى به مثابه يك كهكشان با سياهجاله مر كزى (Tull et al., 2016)

در مركز هر گروه علمى، سياهجالهاى وجود دارد. هنگَامى كه شخص مسير غيرارادى را به سياهُاله سازمان وارد كند، روند تخريب آغاز مىشود. در استعاره كهكشان علمى، گرانش يا

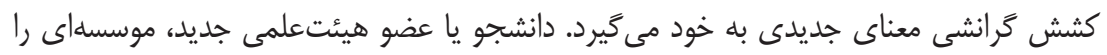

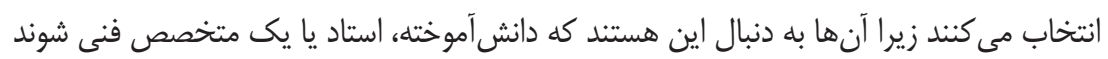
و معتقدند كه اين موسسه مىتواند منابع و آموزههاى لازم را براى موفقيت آنان ارائه كند. تول

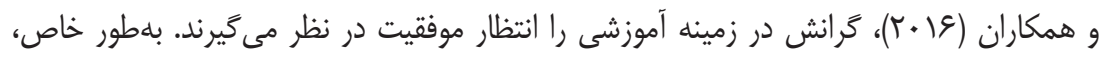
نيروى جذبكنندهاى است كه از اين انتظار حاصل مىشود و مىتواند شامل موفقيت، شناخت، ييشرفت يا دستيابى به نتيجه مطلوب (براى مثال دانشآموختخى، تامين منابع، و ارتقا) شود. شهرت يك گروه آموزشى يا موسسه، افراد باستعدادى را كه به دنبال موفقيت هستند، جذب مي كند. از

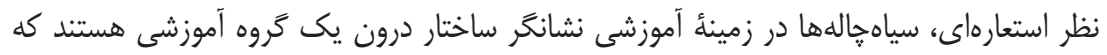
فاقد نور و راهنمايى است؛ دانشجويان و استادان موجود در مدار اين سياهٍاله مشاهده مىشوند. با وجود اين، حركت آنها به سمت سياهٌاله گَروه آموزشى مىتواند نامحسوس باشد. يكى دانشجوى رهاشده و عضو هيئتعلمى كنترلنشده در معرض فرو رفتن در سياهجاله گروه آموزشى قرار دارد. 
ييش از منطقه خاكسترى، افق رويداد يك دانشجو مىتواند نجات يابد، اما دانشجويى كه به حال

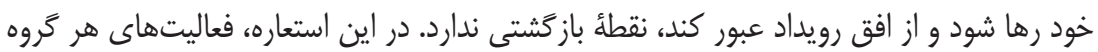

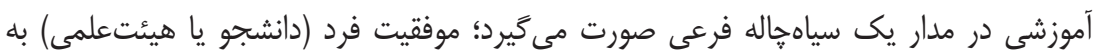
باقى ماندن در مدار فعاليت كمك مى كند، اما شكست در وظايف و مسئوليتهاى محول شده باعث

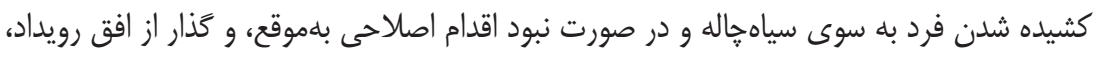
محكوم به سقوط در سياه קاله است.

\section{سياهجاله در اداره امور عمومى}

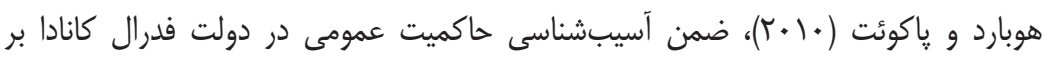
ضرورت اصلاحات اداره امور عمومى تاكيد دارند. آنها كذر از حاكميت بزرگ' (سلسلهمراتبى،

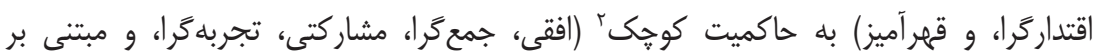

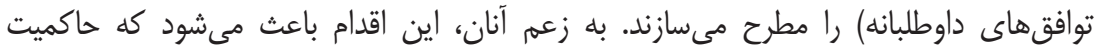

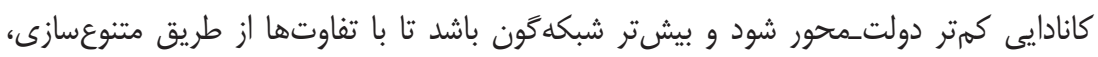

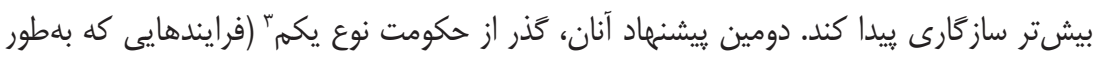

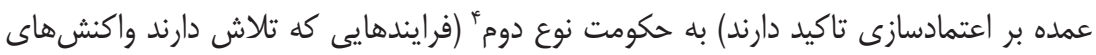

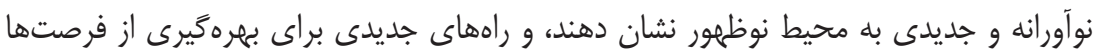

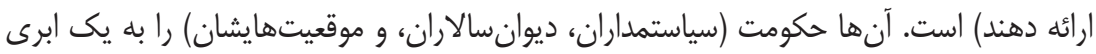

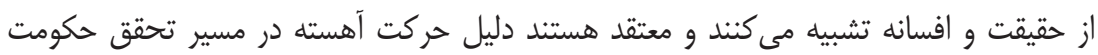
كوجى، اين است كه اخلاق اداره امور عمومى در دولت فدرال كانادا اين روزها به مرحله جديدى النه از ريسكگريزى و در خود جذبشدىى رسيده است. وضعيت بلهَّونهاى است كه حتى موج جديد

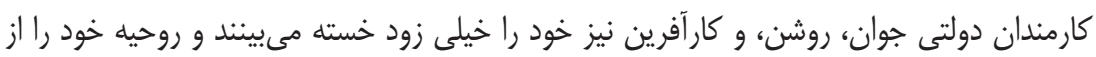

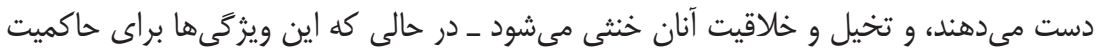

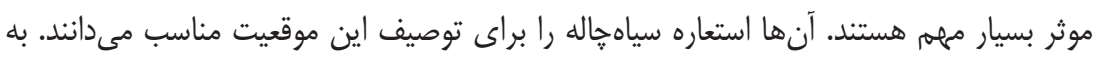

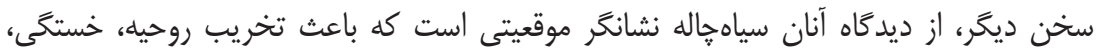

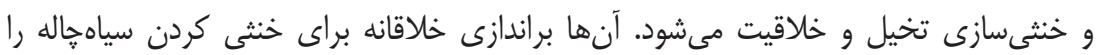

1. 'Big G' government

2. 'Small G' Governance

3. G1

4. G2 
مطرح مىسازند (دعوت به تفكر انتقادى و ايجاد تحول در روند اداره عمومى دولت فدرال)، و تدوين راهبردهاى مناسب را براى سريوش گذاشتن بر سياهٍاله ضرورى و فرار آن را خالش اصلى

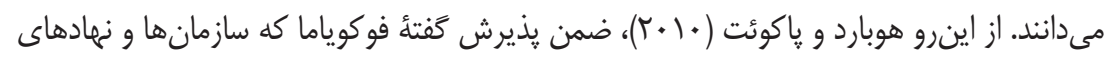
عمومى نهتنها به "جعبه هاى سياه" بلكه به "اسياهخالهها《 شباهت دارند (Fukuyama, 2004)،

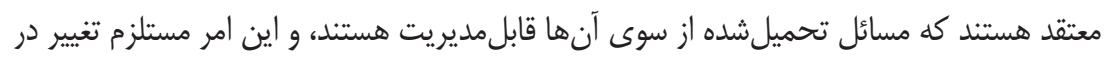
انگًاره اداره امور عمومى است. سياهجاله وجود دارد، اما همه ما محكوم به نابودى در آن نيستيم. اخر

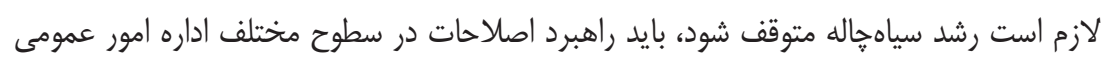
دنبال شود.

\section{سياه جاله در شبكه ارتباطات}

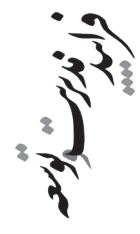

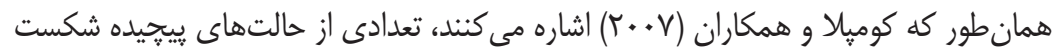
در شبكهها وجود دارد كه سامانههاى فعلى قادر به تشخيص و بازيابى آن نيستند. در مواردى كه شبكه قادر به واكنش خود كار در برابر خرابىها نيست، مداخله دستى لازم است. جنين عملى در مقياسهاى زمانى انسان اتفاق مىافتد، و ممكن است تعداد زيادى از مشتريان تا مدتها به شبكه

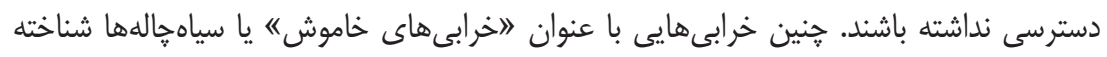
مىشوند، زيرا يروتكلها و دستخاههاى موجود در شبكه هشدار نمىدهند يا باططور خودكار خرابى را برطرف نمى كنند. در شبكه، سياهاله مسيرى' است كه فرو مىرود و غيبت آن در شبكه از سوى ساير مسيرها مشخص نمىشود. بستههايى كه به سياهٍاله فرستاده مىشوند، فرو مىروند.

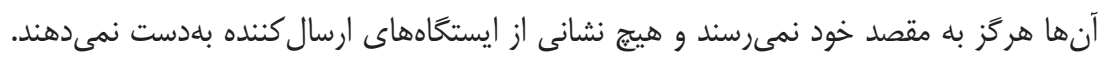

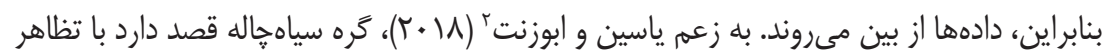
به اين كه هميشه بهترين مسير به گره مقصد است، هر گره كه مىخواهد با كره ديخرى در شبكه ارتباط برقرار كند، فريب دهد. بهطور كلى، سياهخالهها به مكانهايى در شبكه اشاره مى كنند كه در

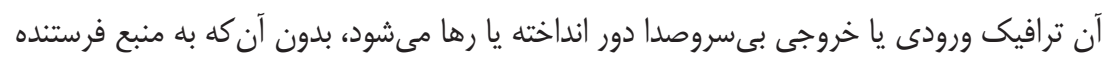
در مورد نرسيدن به دادهها يا به گيرنده مورد نظر اطلاع داده شود (شكل ه).

1. Router

2. Yasin \& Abu Zant 


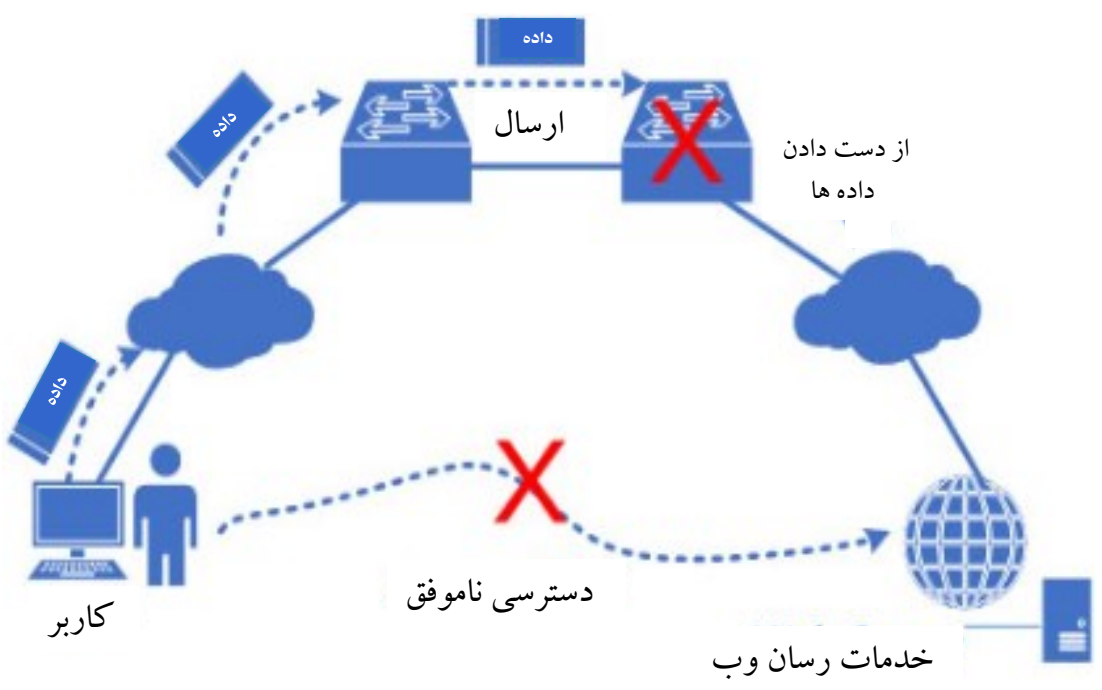

شكل ه: وجود سياهجاله در شبكه ارتباطات

سياهجاله در نظام فرهنكى

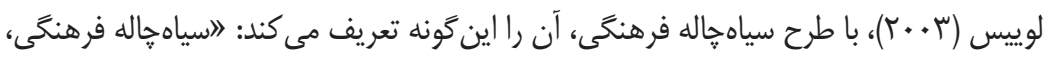

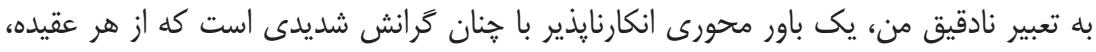

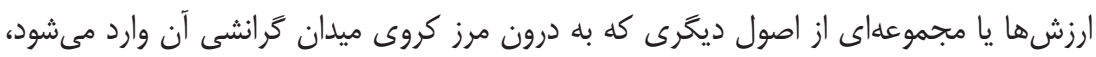

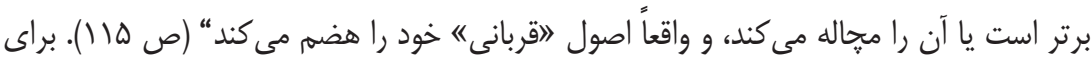

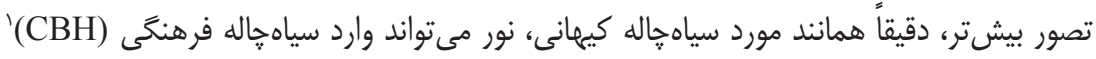

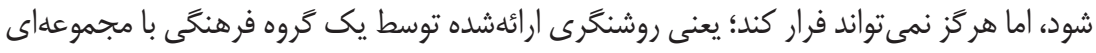

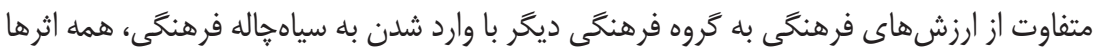

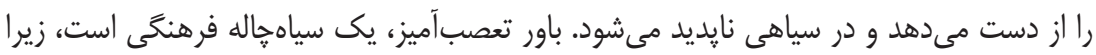

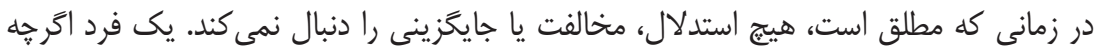

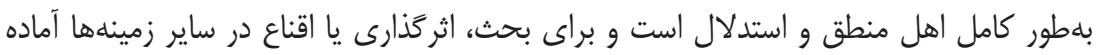

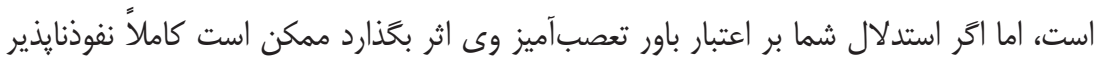

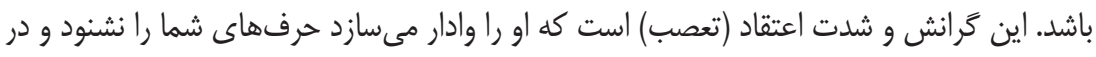

1. Cultural Black Hole 


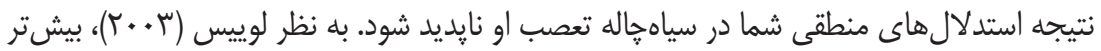

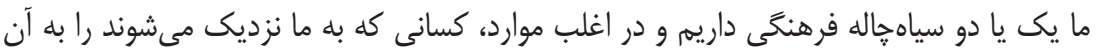

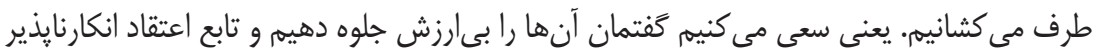
(سياهجاله) خود كنيه. باطور معمول، از اين رفتار خود آكاهى نداريهم.

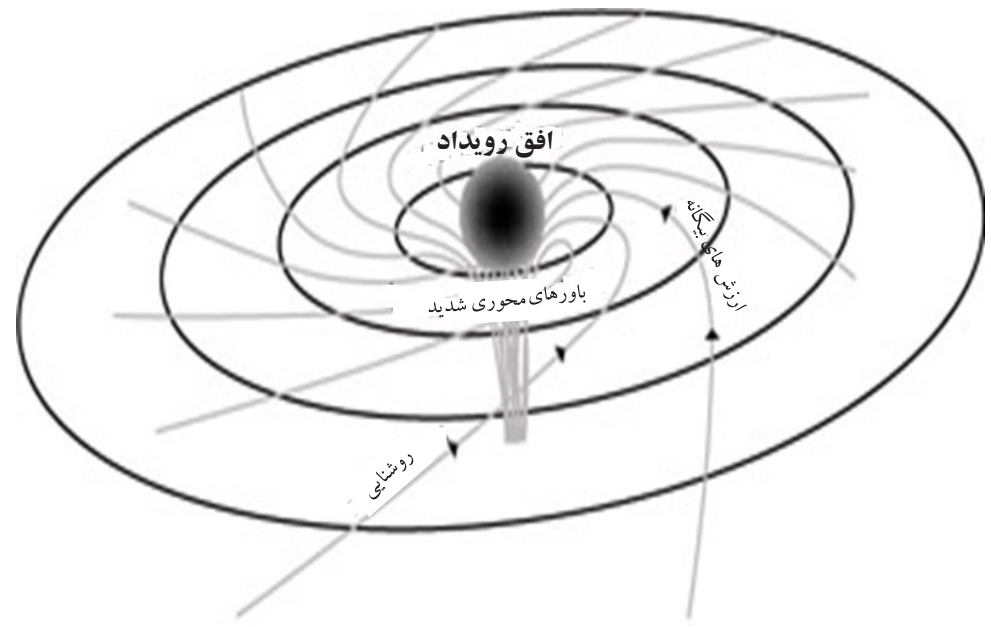

شكل 9: سياهجاله فرهنگى (Lewis, 2003)

\section{سياه جاله سازمانى}

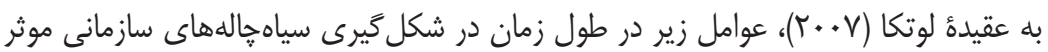

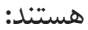

I. رويدادهاى بزرَّ باعث ايجاد تكانه ناگمانى در سازمان مىشوند (مانند ادغام با سازمانهاى

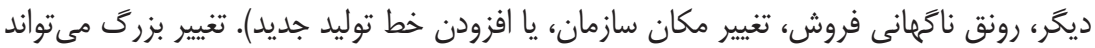

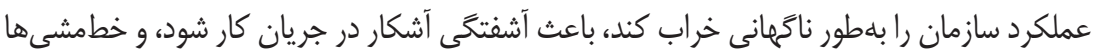

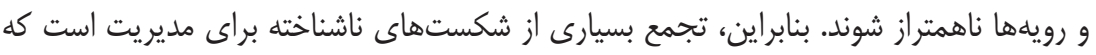

$$
\text { ايجاد سياهزاله مى كند. }
$$

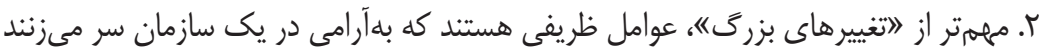

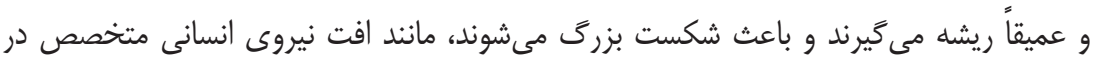


سازمان، تكرار خطاها و اصلاح نكردن آنها؛ اجراى يك رويه جديد بدون آموزش صحيح كاربران؛

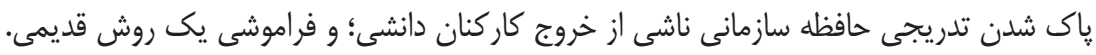

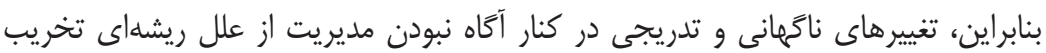

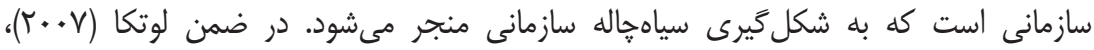

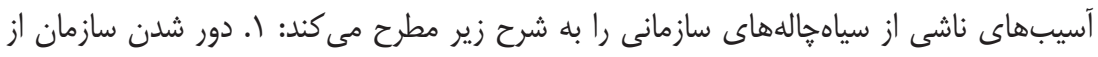

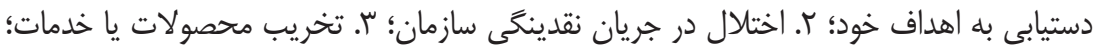
F. كاهش توانايى سازمان در ارائه بلموقع توليدات؛ ه. ناراحتى مشتريان و از دست دادن آنان؛

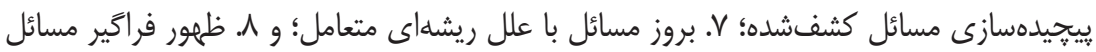

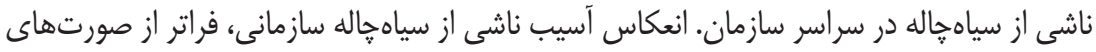

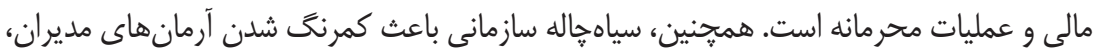
از دست رفتن مشاغل، و كاهش روحيه كاركنان مىشود (Lutka, 2007).

\section{روششناسى در تبيين نظريه}

همانطور كه اشميت' (ه • r) اشاره مى كند، استعاره زمانى تعيين مىشود كه: (. يك كلمه يا عبارت، بتواند فراتر از معناى واقعى در زمينه مشخص درك شود؛ r. معناى واقعى از تجربه فيزيكى تهي

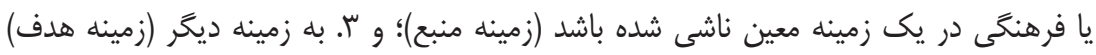

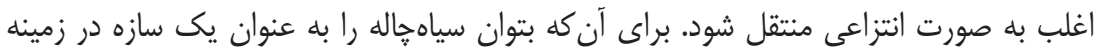

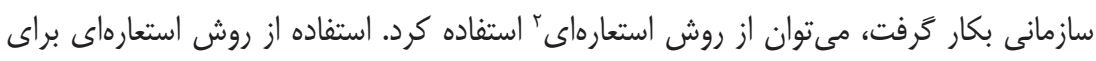

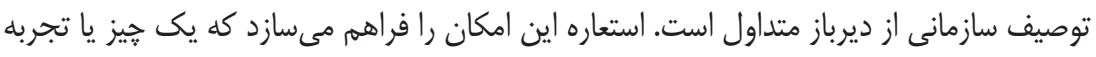

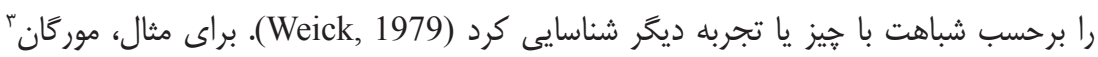

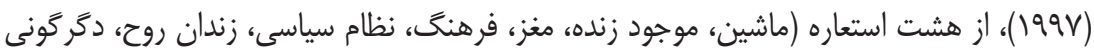

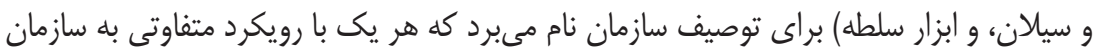

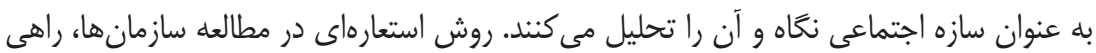

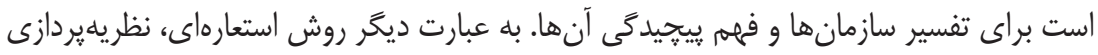

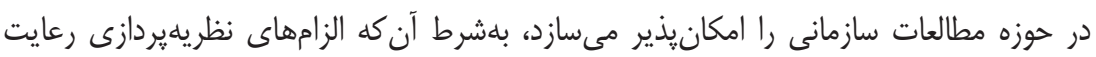

1. Schmitt

2. Metaphor

3. Morgan 
شود. البته همان طور كه لاكوف و جانسون' (1999) اظهار مىدارند، افرادى كه نقش استعاره را در

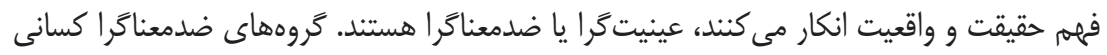
هستند كه هيج نقشى براى استعاره در نشان دادن حقيقت يا واقعيت قائل نيستند.

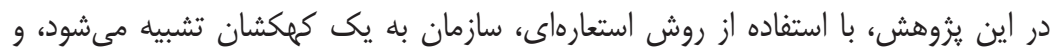

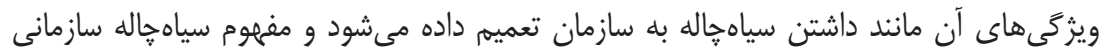

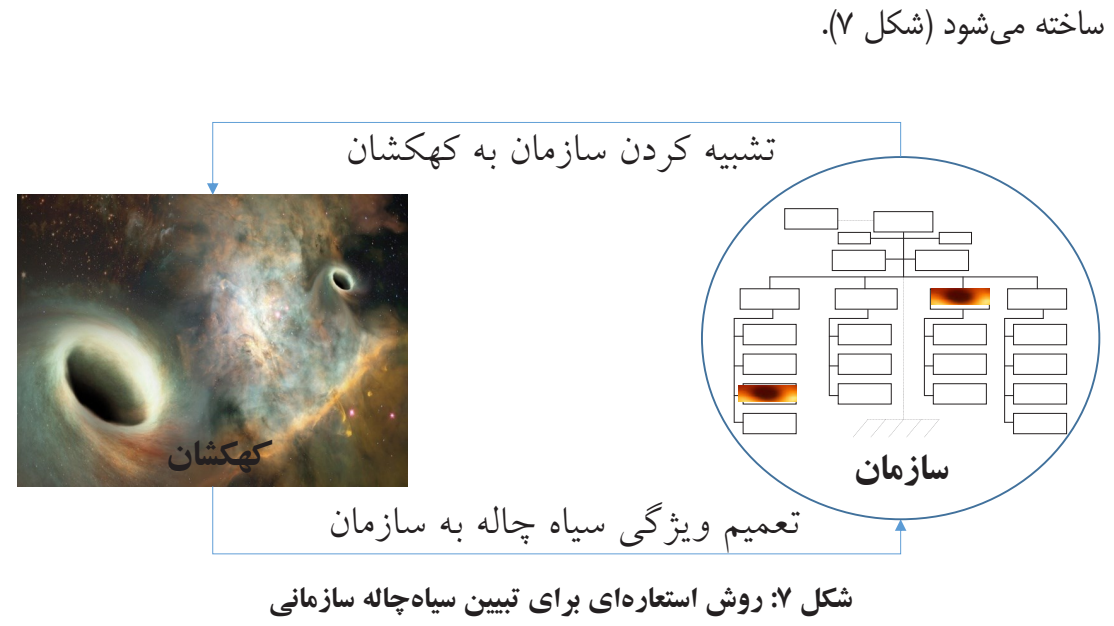

بايد در نظر داشت كه نظريهها بر مبناى گزارههاى تشكيلدهنده به دو دسته تقسيم مىشود

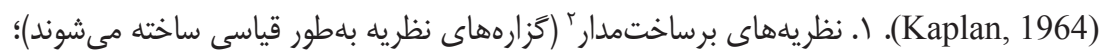

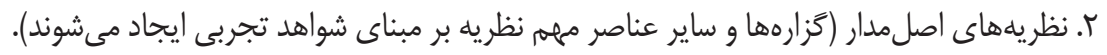

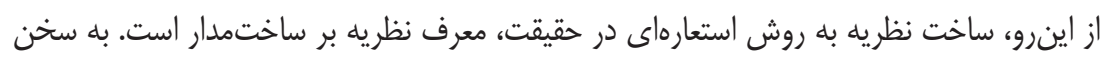

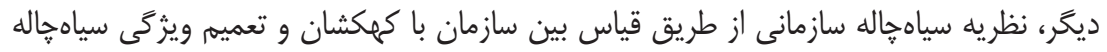
كيهانى به سازمان ساخته مىشود.

\section{ساخت نظريه سياه خاله سازمانى}

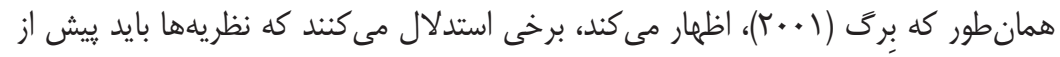

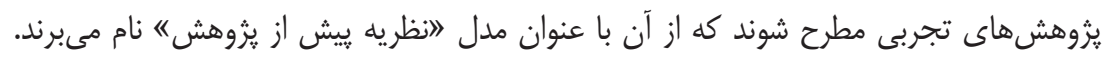

2. Constructive 
اين جهت گيرى بهخوبى توسط يوير' (1981) شرح داده مىشود، وقتى مى گويد فرد با نظريهير دازى

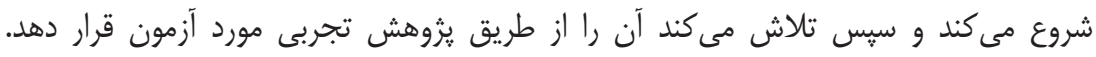

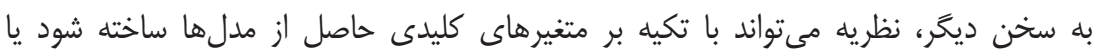

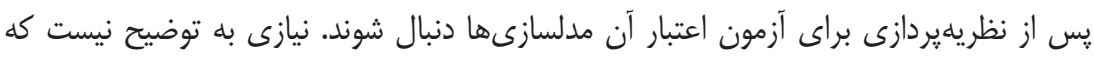

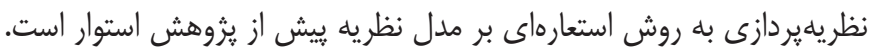

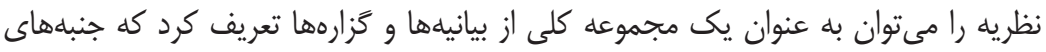
مختلف برخى از يديدهها را توصيف مى كند (Babbie, 1998). در يك زمينه كاربردى، نظريهها

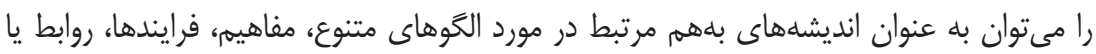

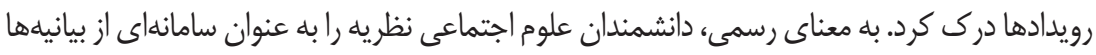

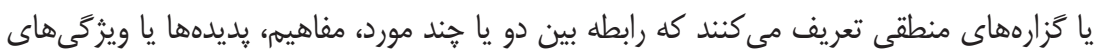

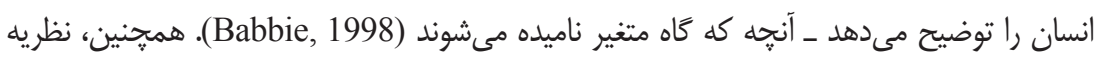

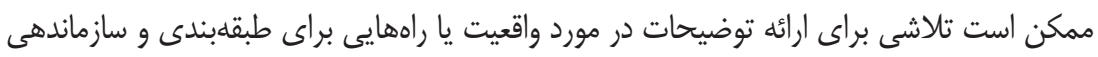

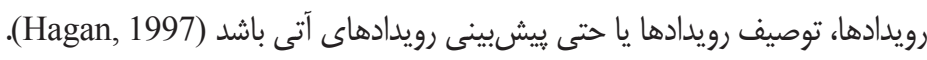

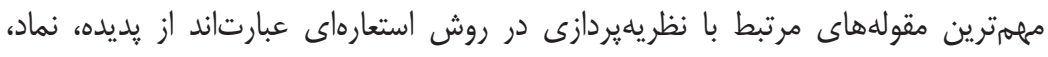

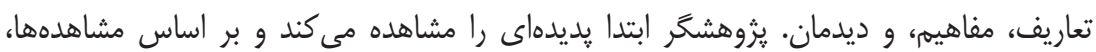

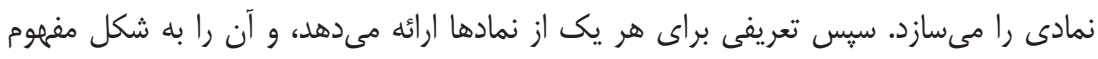

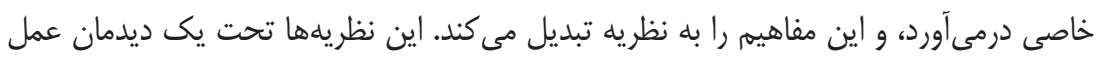

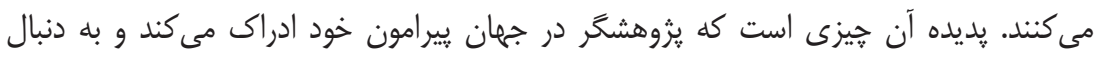

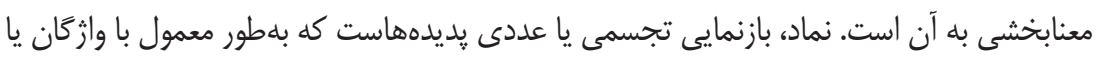

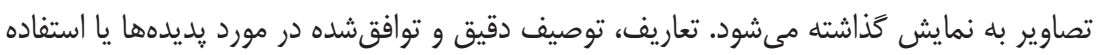

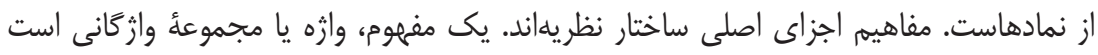

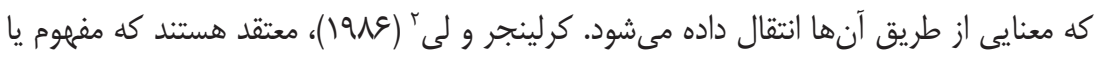

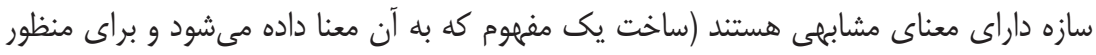

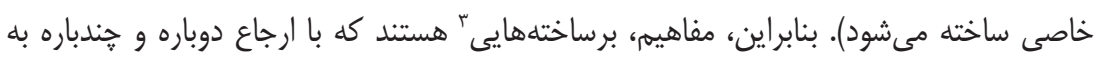

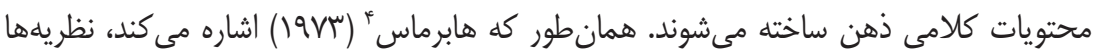

1. Popper

2. Kerlinger \& Lee

3. Construct

4. Habermas 
جيزى بيش از خار خوبهاى نظامبخش نيستند. هرجند در علوم طبيعى نظريdهايى ساخته مىشود كه نشانگر نوعى شناخت است و به سلطه ابزارى بر طبيعت مىانجامد، اما وقتى همين روش در

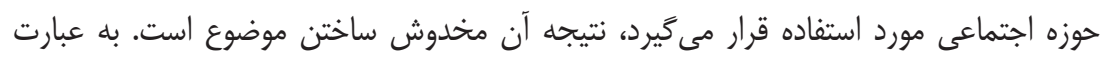

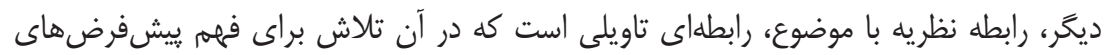

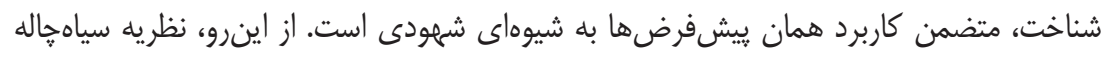
سازمانى را بايد از نوع تاويلى بلشمار آورد.

\section{تعريف سياهجاله سازمانى}

اولين كام در ساخت نظريه به روش استعارهاى، ارائه تعريف مناسب از سياهخاله سازمانى است. به عبارت ديخر، توصيف دقيق و توافقشده در مورد يديده سياهُاله سازمانى يا استفاده از نمادها. करें

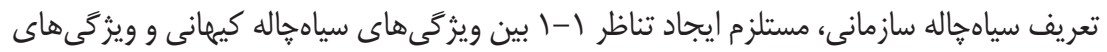

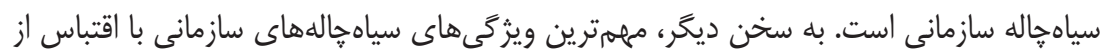

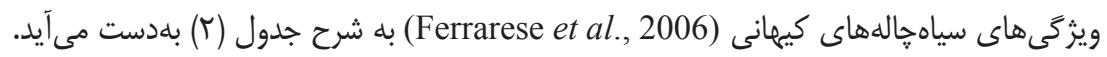

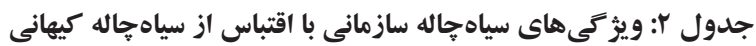

\begin{tabular}{|c|c|c|}
\hline سياهجاله سارمانى & سياهجاله كيهانى & رديف \\
\hline 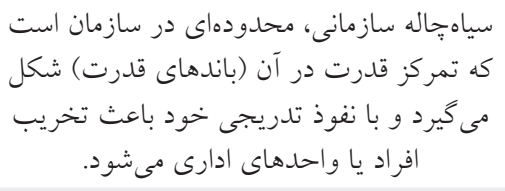 & 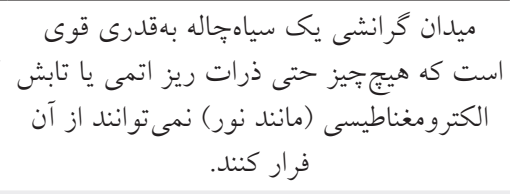 & 1 \\
\hline 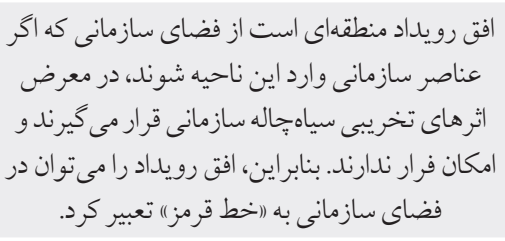 & 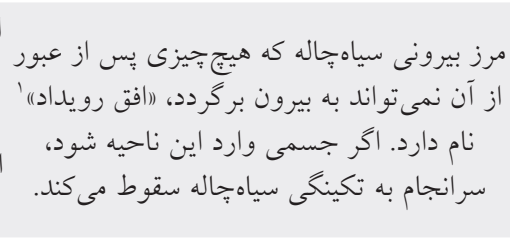 & r \\
\hline 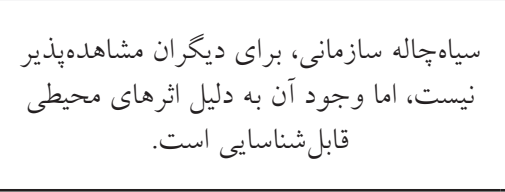 & 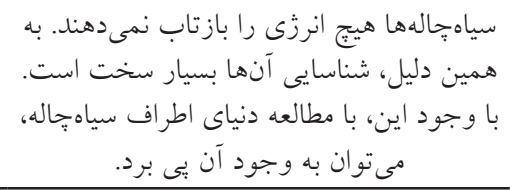 & $r$ \\
\hline
\end{tabular}

1. Singularity 
ادامه جدول بّ: ويزگى هاى سياهجاله سازمانى با اقتباس از سياهجاله كيهانى

\begin{tabular}{|c|c|c|}
\hline سياهجاله سازمانى & سياهجاله كيهانى & رديف \\
\hline 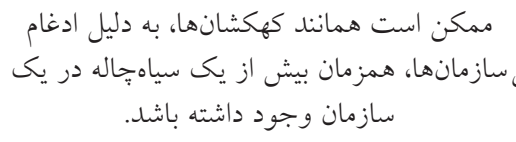 & 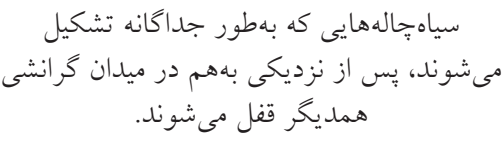 & r \\
\hline 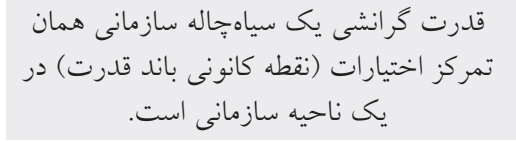 & 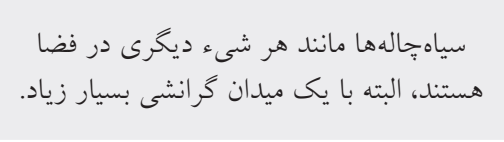 & $\theta$ \\
\hline 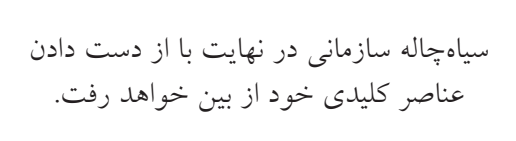 & 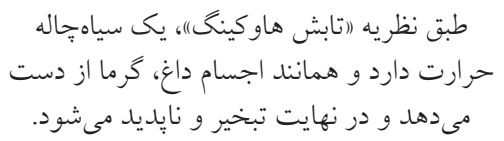 & 4 \\
\hline سياهجاله سازمانى اثرهاى منفى دارد كه براى & 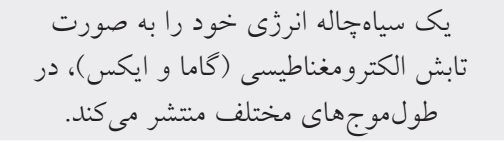 & V \\
\hline 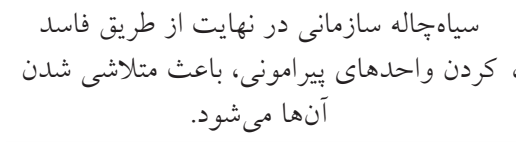 & 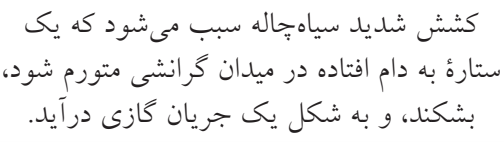 & $\wedge$ \\
\hline 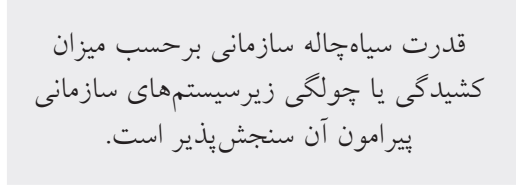 & 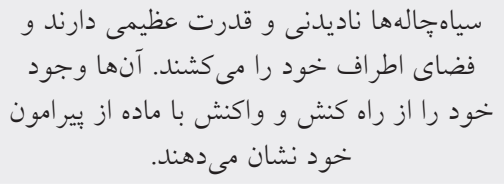 & 9 \\
\hline با ادغام سازمانها، امكان شكل شيرى سياهِاله & 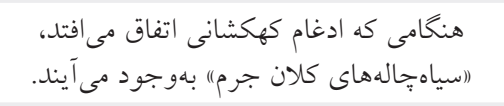 & 1. \\
\hline 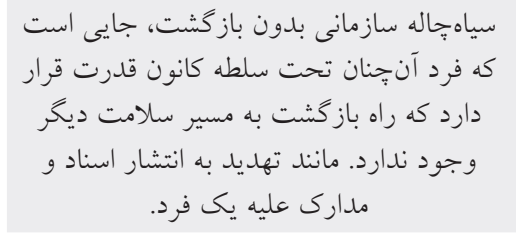 & 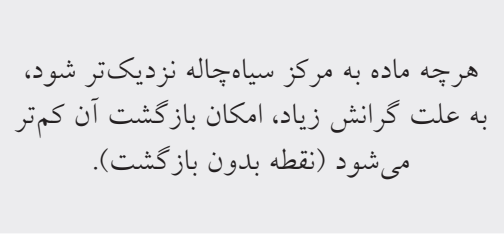 & 11 \\
\hline 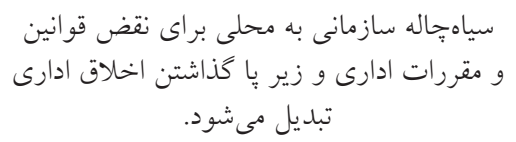 & در مركز سياهِّاله (تكينگى)، كليه قوانين & $\pi$ \\
\hline
\end{tabular}


با توجه به ويزگىهاى اشارهشده در جدول (Y)، مىتوان سياهياله سازمانى را به شرح زير

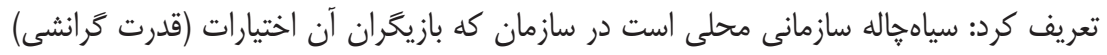

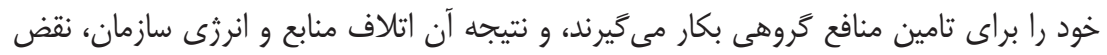
قوانين و مقررات، آسيبرسانى، و تخريب تدريجى زيرسيستمهاى سازمانى است.
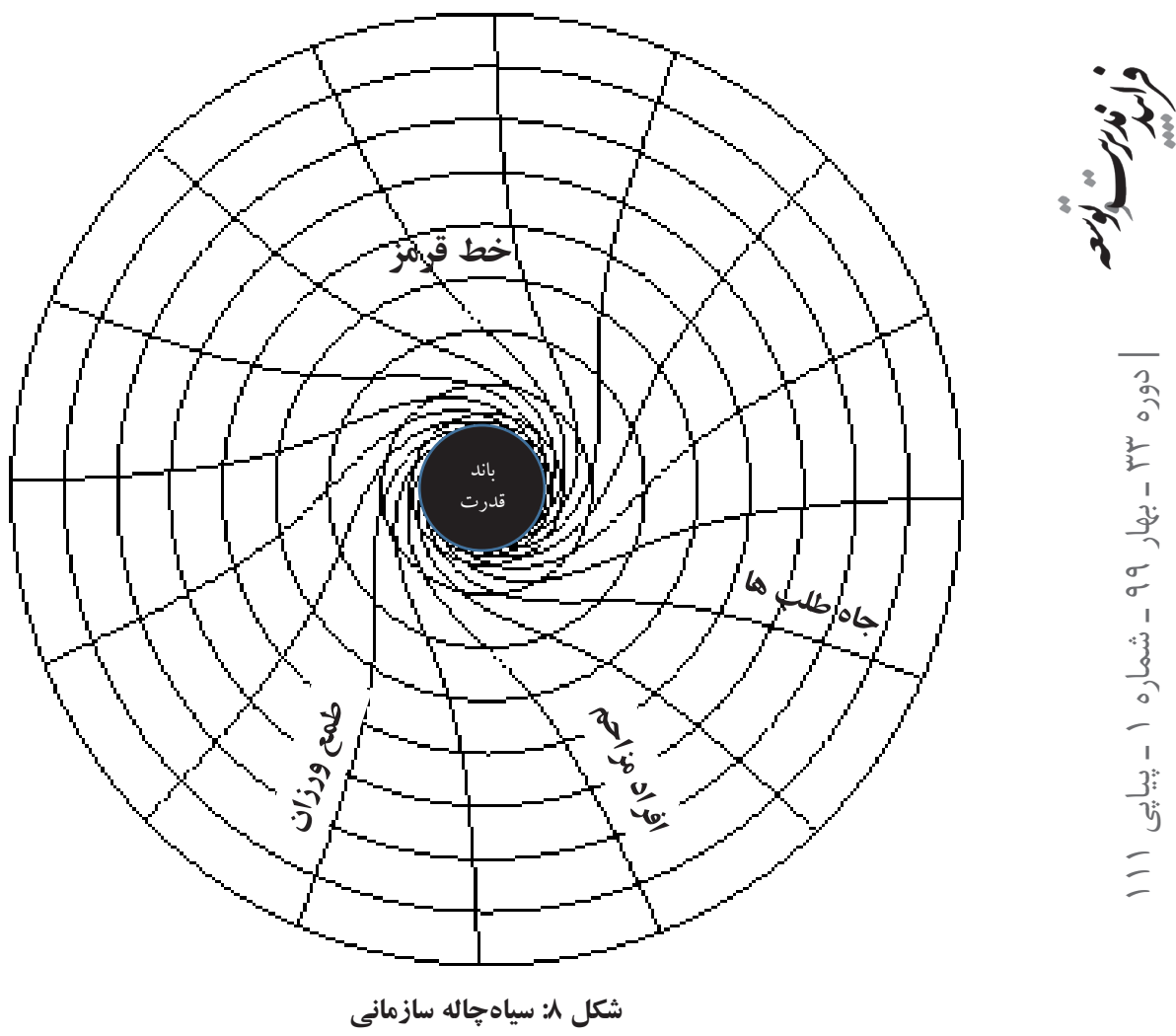

2
2
2
2
1
3
3
$\sigma$
0
$\vdots 3$
3
0
1
3
3
$=$
$=$

همانطور كه در شكل (ᄉ) ديده مى شود، باند قدرتى كه در يك ناحيه از سازمان شكل مى گيرد،

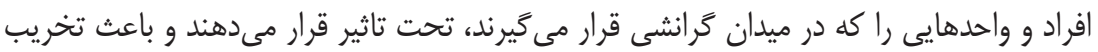

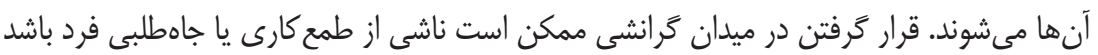

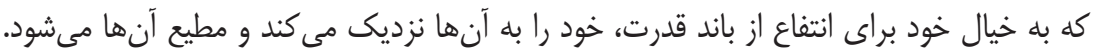
حنين افرادى براى آنكه اعتماد باند قدرت را جلب كنند، بلطور معمول دست به اقدات اقدامهايى 
مىزنند كه خلاف قوانين و مقررات يا اخلاق حرفهاى و ادارى است. آنها دست به خبر خينى در

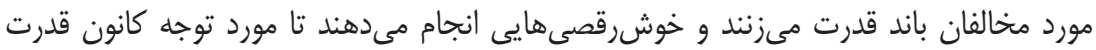

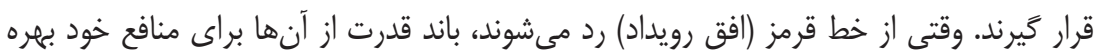

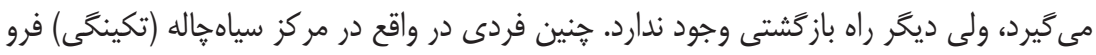

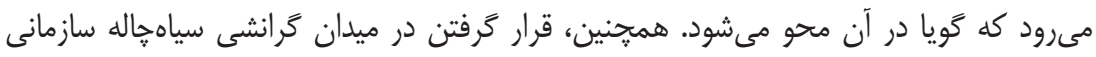

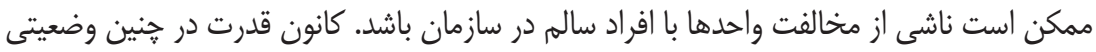

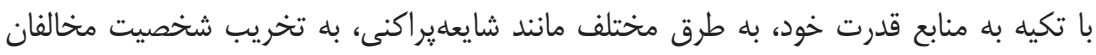

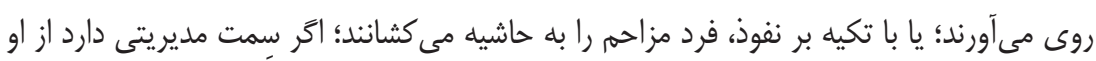

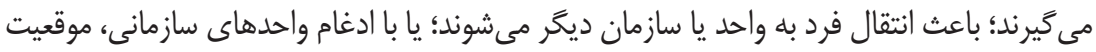

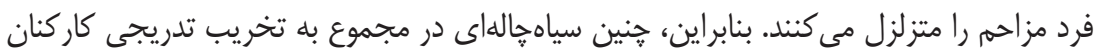
سالم سازمان منجر مىشود.

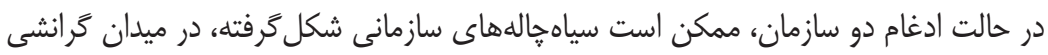

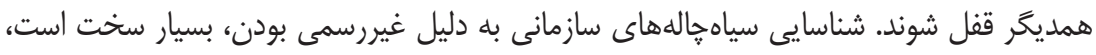

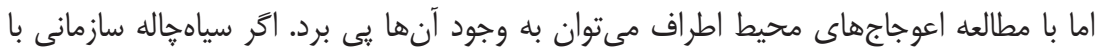

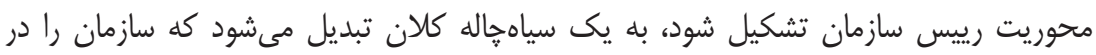

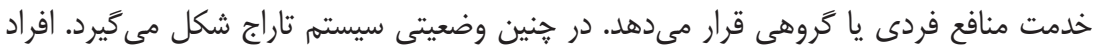
خودى جذب سازمان مىشوند و در لايههاى مختلف بكار كرفته مى شوند، و سازمان بان به تسخير

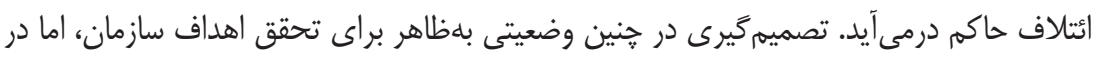

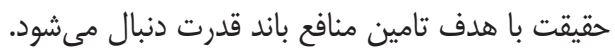

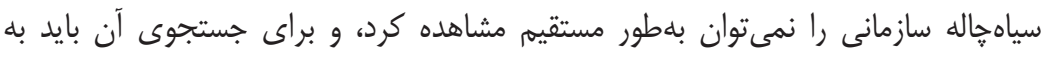

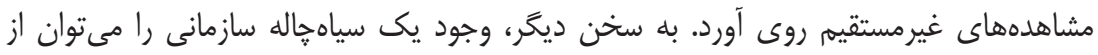

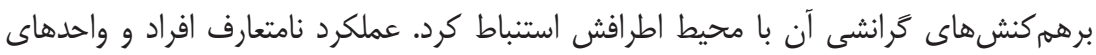
سازمانى در اطراف سياهياله سبب مىشود كه وجود آن رادر سازمان احساس كنيه. يكى از راههاى

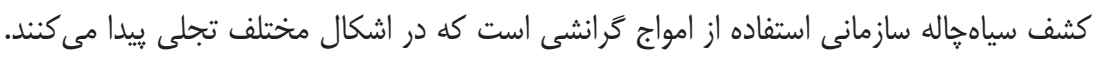

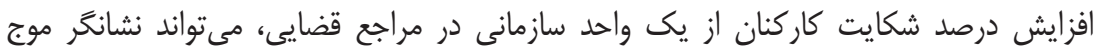

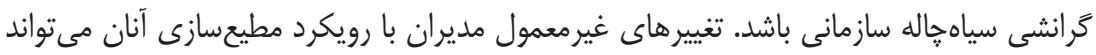

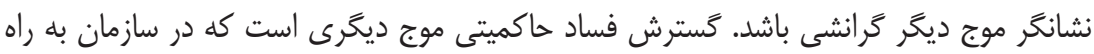


همانند سياهجاله كيهانى، سياهجاله سازمانى نيز تبخير و محو مىشوند. اين تبخير مىتواند

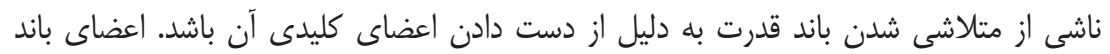

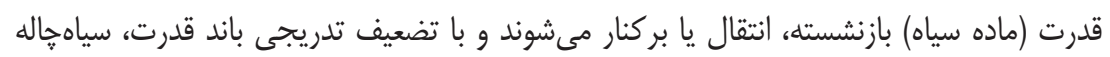
سازمانى در نهايت محو مىشوند. سياه جاله سازمانى با در ييش كرفتن راهبرد تاراج، باعث نارضايتى

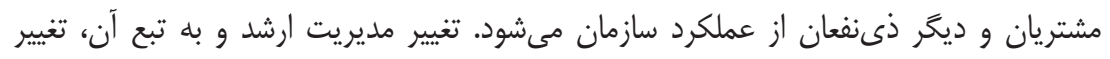

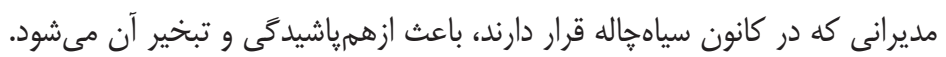

\section{ديدمان ناظر بر نظريه سياهُ جاله سازمانى}

به زعمم كوهن' (1999)، علم از راه انباشت خطى تكامل نمىيابد، بلكه تكامل از راه تغيير

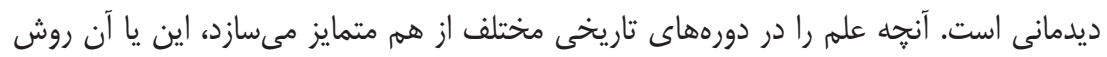
की

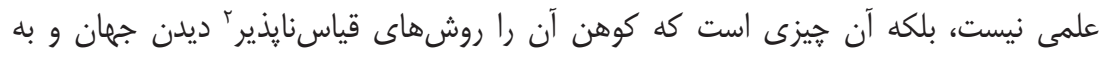

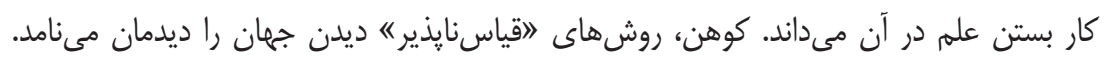

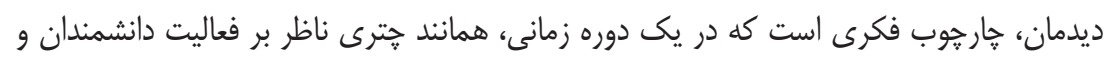

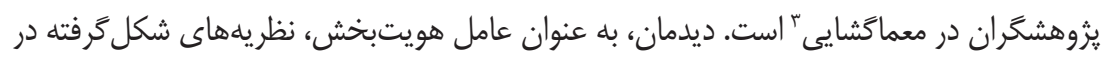

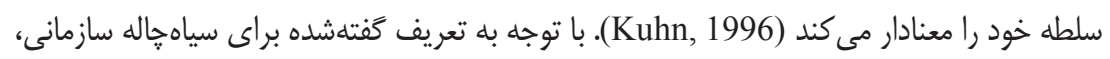

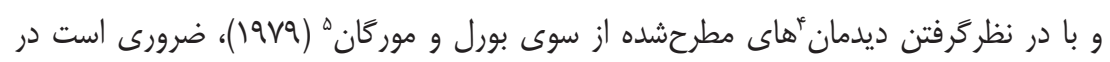

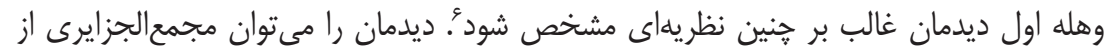

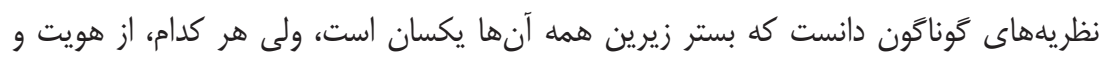
مختصاتى انحصارى و ويزه برخوردار است (Vasquez, 1998).

1. Kuhn

2. Incommensurable

3. Puzzle-Solving

4. Paradigm

5. Burrell \& Morgan

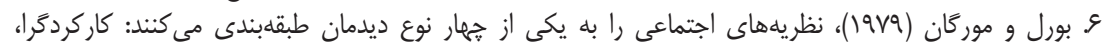
تفسير كرا، انسان كراى بنيادى، و ساختاركًراى بنيادى. 


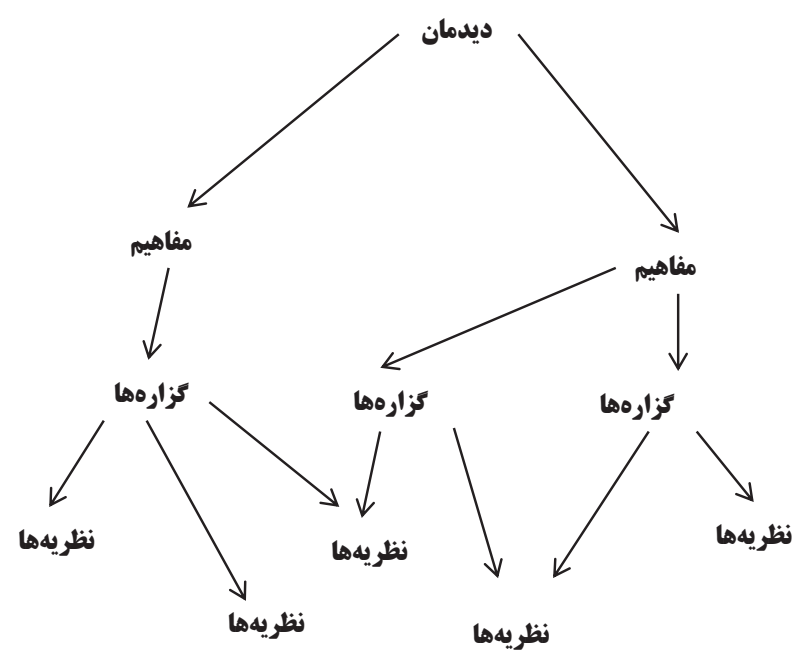

شكل 9: روابط تحليلى بين ديدمان و نظريه (Vasquez, 1998: 23)

نظريه سياهٍاله سازمانى، از نظر هستى شناسى بر ذهنى گرايى تكيه دارد. به سخن ديخر، پيديده مورد مطالعه ساخته و يرداخته ذهن انسان است كه به روش استعارهاى ساخته مى شود. از نظر روششناسى بر ايدهنگارى استوار است؛ يعنى يخوهشگَر انخارههاى خود را بر موضوع مورد مطالعه

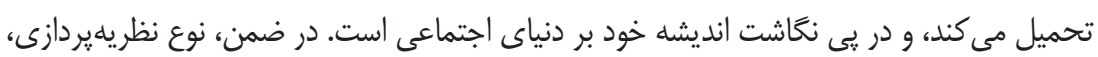

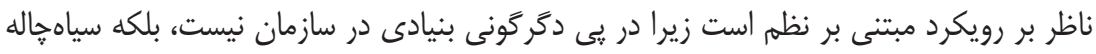

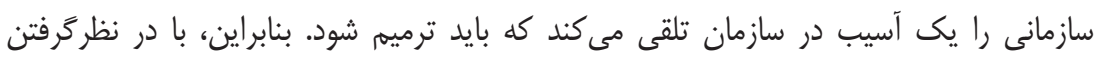

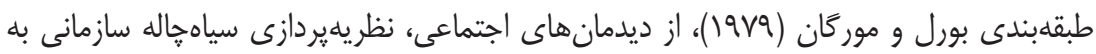
روش استعارهاى با ييشفرض هاى ديدمان تفسير گرايى همخوانى دارد (شكل • (1). 

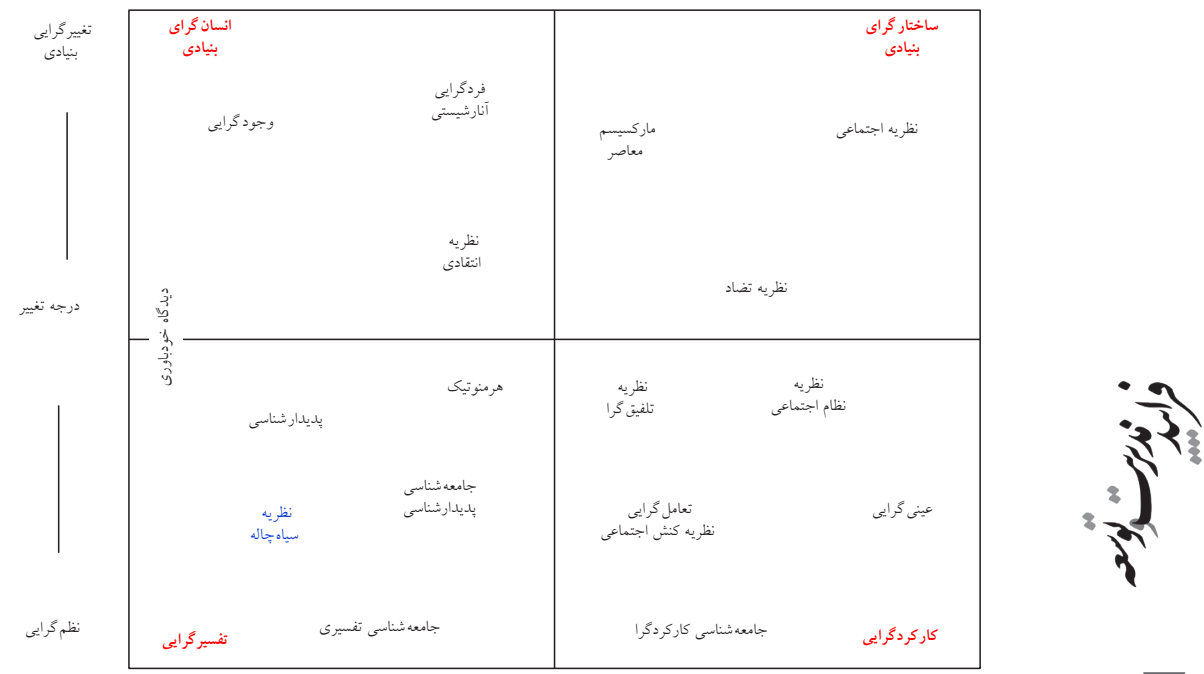

شكل • ا: ديدمان ناظر بر نظريه سياهٍاله سازمانى

ديدمان تفسيرگر| علاقهمند است ماهيت بنيادى جهان اجتماعى را در سطح تجربه ذهنى بشناسد. مطابق اين ديدمان، سازمانها بايد به صورت ساختبندىهاى اجتماعى تلقى شوند؛

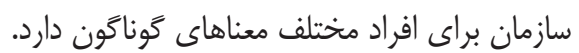

\section{ابطال يذيرى و سودمنلى نظريه سياه جاله سازمانى}

يك نظريه علمى امجموعئ سازمانيافتهاى از گزارههايى است كه به تعريف، توصيف روابط،

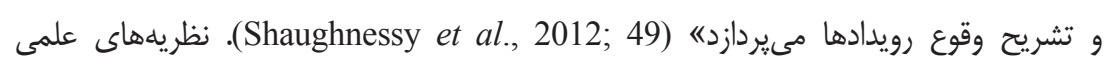
موفق به سازماندهى دانش تجربى، و با ارائه فرضيههاى آزمونيذير، يثوهش را ها هدايت مى كند.

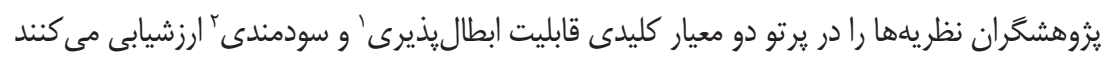
(Popper, 1968; Nagel, 1961; Hempel, 1965) يك نظريه باكَّنهاى ساخته مىشود كه رد تجربى آن امكانيذير باشد. به سخن ديخر، بايد اين امكان وجود داشته باشد كه يك سيستم علمى تجربى از طريق آزمايش رد شود. نظريه سياهِاله سازمانى از

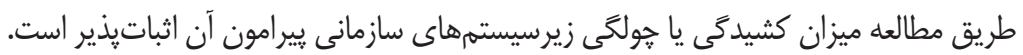

2. Utility 
سودمندى نشانكر مفيد بودن منظومههاى نظرى است. همانطور كه بيرستد' (1909)

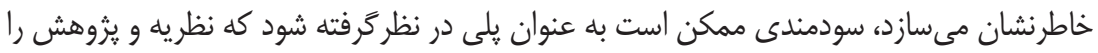

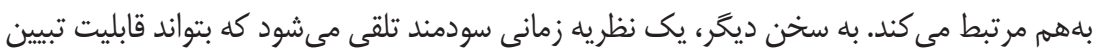

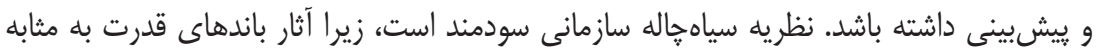

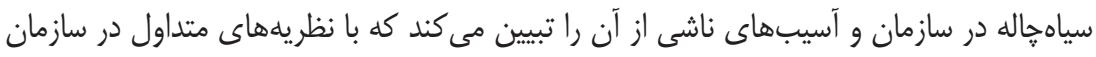

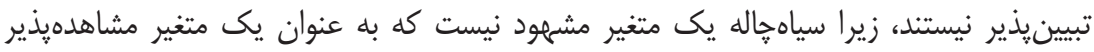
اندازمخيرى و اثر آن بر ديخر متغيرهاى وابسته مطالعه شود.

\section{كونهشناسى سياهجاله هاى سازمانى}

سياهِالههاى سازمانى بر اساس دو ويزَّى موقعيت (محل قرارَيرى)، و قدرت كَرانشى (نفوذ

بر محيط) به جهار دسته تقسيم مىشوند.

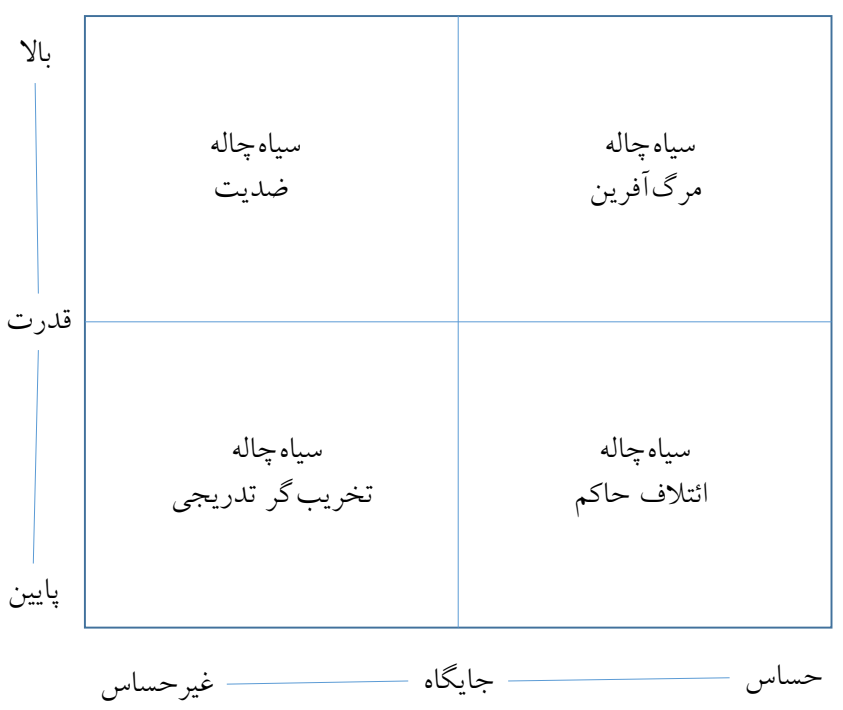

شكل 11: ونهناسى سياهجالههاى سازمانى

همانطور كه در شكل (II) ديده مىشود، در سازمانى كه سياهياله شكلَّفته از جايخاه

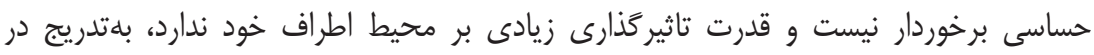


نقش تخريبگر محيط داخلى سازمان ظاهر مىشود (سياهجاله تخريبگر تدريجى). در نقطه مقابل،

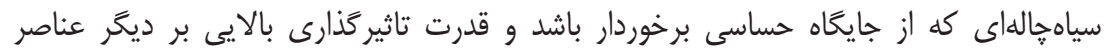

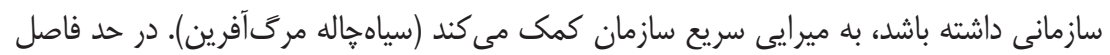

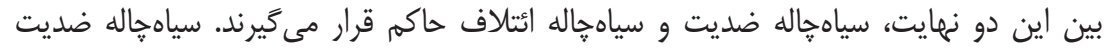
نشانكر محلى است در سازمان كه به كانون مخالفت با مديريت ارشد تبديل مى شيود و در قالب

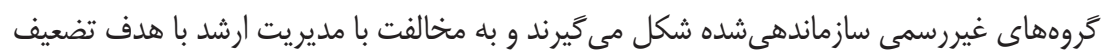

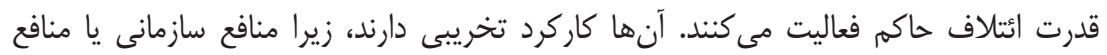

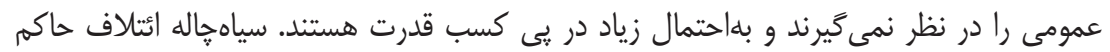

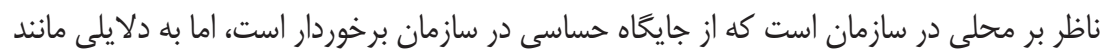

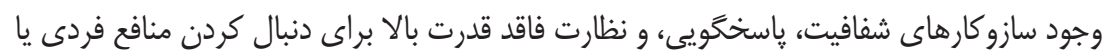
كروهى است. هنين سياهجاله سازمانى به دليل فقدان شايستخى به تصميمهايى اقدام مى كند كه

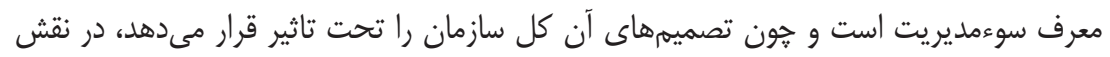
تخريبى عمل مى كند.

\section{بحث و نتيجه كيرى}

هدف يزوهش تبيين فعاليتهاى تخريبى در سازمان مبتنى بر ديدمان تفسير كرايى است كه به

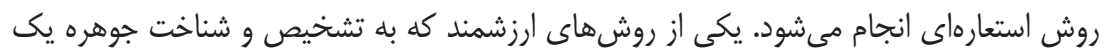

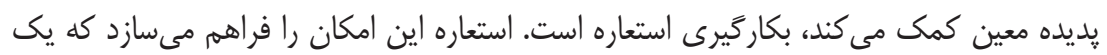

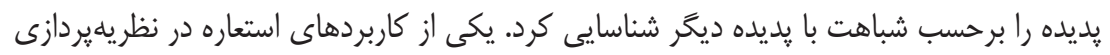

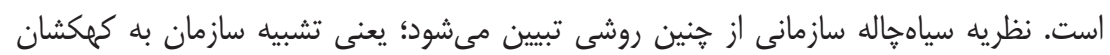

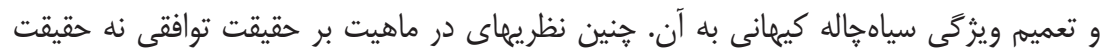

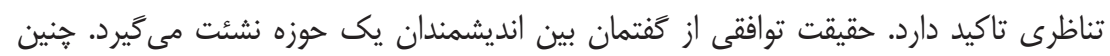

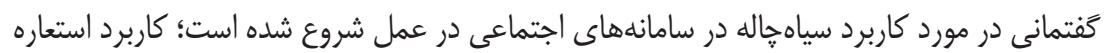

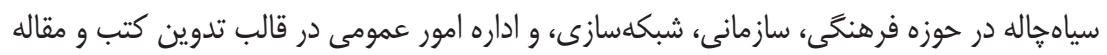
بيانكر هنين ادعايى است.

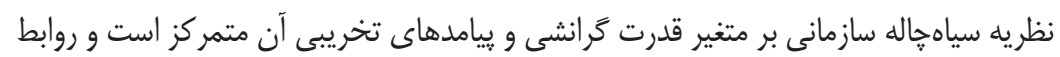

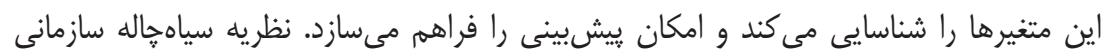

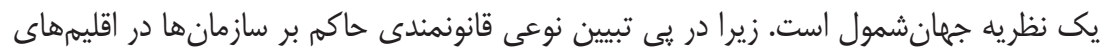


فرهنگى مختلف است. اين نظريه قابليت ابطاليذيرى دارد، زيرا مىتوان از طريق سنجش درجه

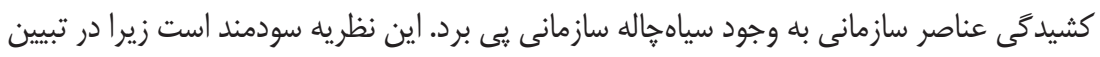

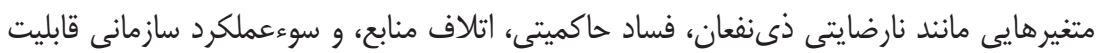

يبشيبى دارد.

نظريه سياه هاله سازمانى به روش استعارهاى ساخته مىشود. اين نظريه از ديدمان تفسيرَّرايى

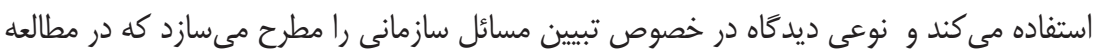

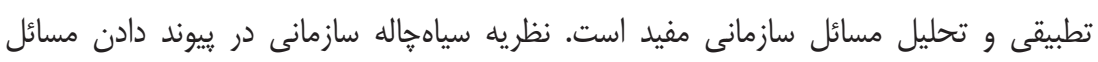

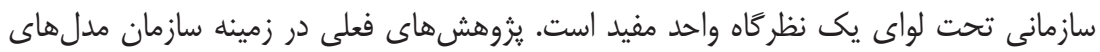

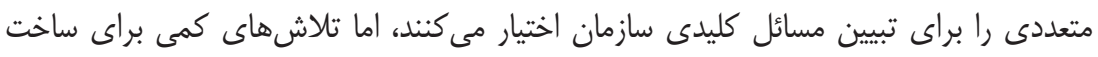

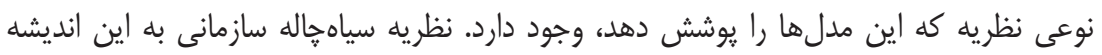

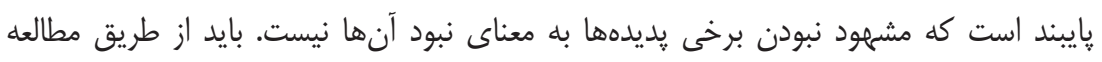

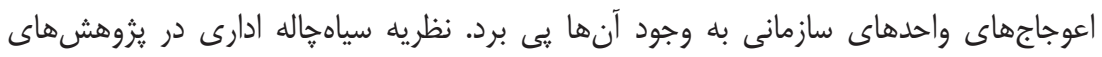

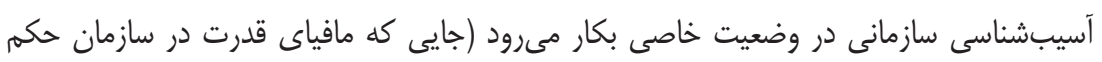

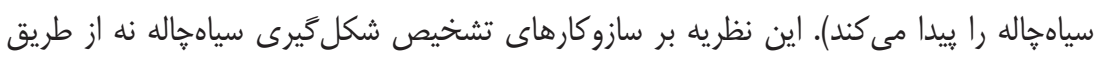

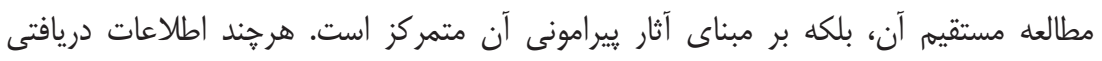

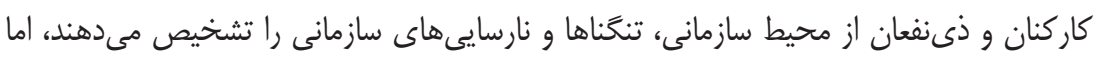

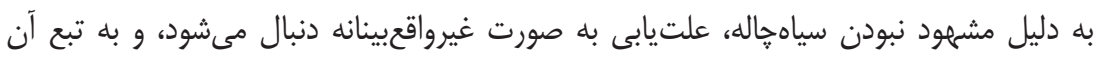

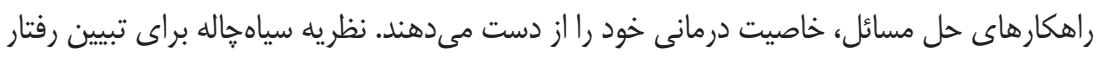

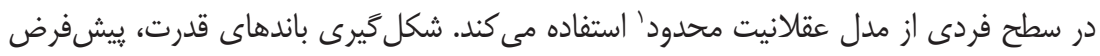
عقلانيت محدود را تاييد مى كند. نظريه سياهجاله سازمانى تبيين متفاوتى را از فعاليتهاى تخريبى در مارد سازمان ارائه مىدهد.

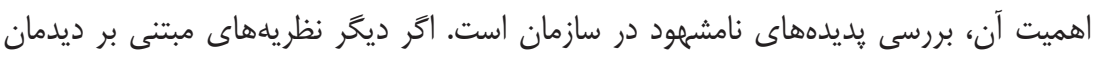

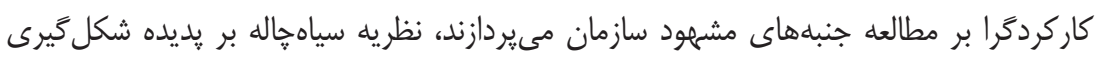

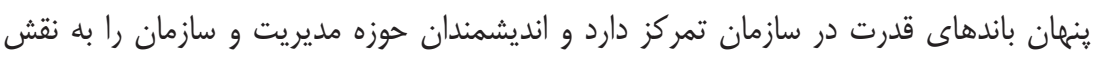

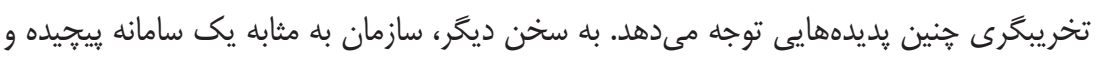

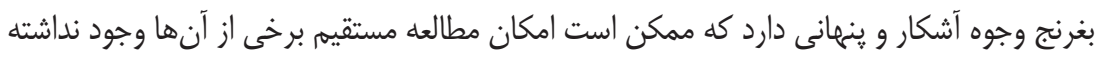

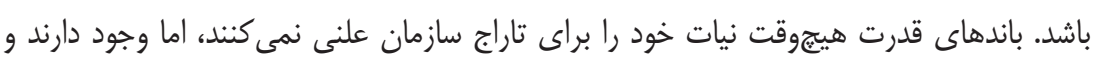

1. Bounded Rationality 
كاركرد تخريبى آنها انكارنايذير است. نظريه سياهُاله سازمانى، با تمركز بر آثار تخريبى جنين يديدههايى، وجود آنها را اثبات و مطالعه در خصوص شكل گيرى، رشد، و تبخير آنها را توصيه مى كند. از اينرو ييشنهاد مىشود، بر مبناى نظريه سياهجاله سازمانى، مدلسازى در سازمانىهاى مختلف بخش عمومى و خصوصى دنبال شود. همانطور كه استروم' (V... (T) اشاره مىكند، مدلها ييشفرضهاى دقيقى در مورد مجموعه معدودى از يارامترها و متغيرها مىسازند. مدلها

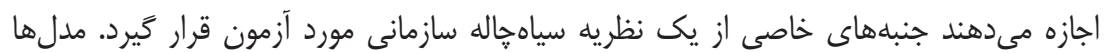
به تحليلگران اجازه مىدهند با ثابت نحهداشتن تعداد معدودى از متغيرها در محيطهاى خاص و و

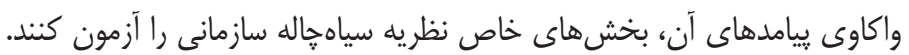

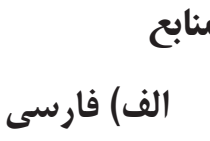

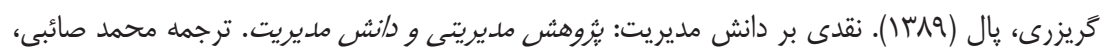
يزوهشگاه حوزه و دانشگاه.

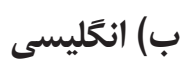

Babbie, E. R. (1998). The Practice of Social Research.International Thomson Publishing Services.

Berg, B. L. (2001). Quantitative Research Methods for the Social Sciences. Allyn \& Bacon.

Bierstedt, R. (1959). Nominal and Real Definitions in Sociological Theory. In

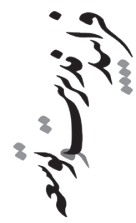
L. Gross (Ed.). Symposium on Sociological Theory, New York: Harper \& Row: 121-144.

Burrell, G., \& Morgan, G. (1979). Sociological Paradigms and Organizational Analysis Heinemann. London: UK.

Cox III, J., \& Schleier, J. (2010). Theory of Constraints Handbook. McGraw-Hill. Ferrarese, L., Colpi, M., Gorini, V., Haardt, F., \& Moschella, U. (2006). Joint Evolution of Black Holes and Galaxies. Taylor \& Francis.

Fukuyama, F. (2004). State Building: Governance and World Order in 21st Century. Cornell University Press.

Gardner, T. (2011). The Bermuda Triangle of Organizational Change.

1. Ostrom 
Retrieved from thehrintrovert.com/2011/03/the-bermuda-triangle-oforganizational-change/

Goldratt, E. (2010). 1-Introduction to TOC-My Perspective. McGraw Hill Professional.

Habermas, J. (1973). Theory and Practice. Trans. J. Viertel, London. Heinemann.

Hagan, F. E. (1997). Research Methods in Criminal Justice and Criminology. Allyn and Bacon Boston.

Hempel, C. G. (1965). Aspects of Scientific Explanation: And Other Essays in the Philosophy of Science. Free Press.

Hubbard, R., \& Paquet, G. (2010). The Black Hole of Public Administration. University of Ottawa Press.

Kaplan, A. (1964). The Conduct of Inquiry: Methodology for Behavioral Research. Scranton, PA: Chandler Publication.

Kerlinger, F., \& Lee, H. (1986). Observations of Behavior and Sociometry. Foundations of Behavioral Research. 3rd Ed. New York: Holt, Rinehart \& Winston, 486-493.

Kiel, L. D., \& Elliott, E. W. (1996). Chaos Theory in the Social Sciences: Foundations and Applications. University of Michigan Press.

Kieżun, W., \& Bielecki, C. (2012). Patologia Transformacji. Wydawnictwo Poltext.

Kompella, R. R., Yates, J., Greenberg, A., \& Snoeren, A. C. (2007). Detection and Localization of Network Black Holes. Paper Presented at the IEEE INFOCOM 2007-26th IEEE International Conference on Computer Communications.

Krasner, S. (1990). The Ubiquity of Chaos. American Association for the Advancement of Science.

Kuhn, T. S. (1996). The Structure of Scientific Revolutions: University of Chicago.

Lakoff, G., \& Johnson, M. (1999). Philosophy in the Flesh: The Embodied Mind and Its Challenge to Western Thought (Vol. 640). Basic books New York.

Lewis, R. D. (2003). The Cultural Imperative: Global Trends in the 21st Century. Intercultural Press Yarmouth, ME.

Lutka, R. (2008). Black Holes in Accounting. Black Holes-Areas of Undesirable Activities That Go Unchecked. CMA Management, 82(2), 24.

Lutka, R. (2014). Black Holes in Organizations. Define Dissect Diffuse: iUniverse

Morgan, G. (1997). Images of Organization. Sage Publication. 
Nagel, E. (1961). The Structure of Science: Problems in the Logic of Scientific Explanation. Harcourt, Brace \& World.

Nardo, D. (2004). Black Holes: Lucent Books.

Ostrom, E. (2007). Institutional Rational Choice. An Assessment of the Institutional Analysis and Development Framework, in Sabatier, P.A., and Weible, C.M. (Eds.) Theories of the Policy Process, 3rd Edition, Colorado: Westview Press.

Popper, K. R. (1968). Kant's Critique and Cosmology'in Conjectures and Refutations: The Growth of Scientific Knowledge. Harper and Row.

Schmitt, R. (2005). Systematic Metaphor Analysis as a Method of Qualitative Research. The Qualitative Report, 10(2), 358-394.

Shaughnessy, J., Zechmeister, E., \& Zechmeister, J. (2012). Observation. Research Methods in Psychology (9th ed.), Ed JJ Shaughnessy, E. B. and J. S Zechmeister (New York, NY: McGraw-Hill Companies), 92-136.

Sroka, W., \& Cygler, J. (2014). Pathologies in Inter-Organizational Networks. Procedia Economics and Finance, 12(1), 626-635.

Tull, R. G., Tull, D., Hester, S., \& Johnson, A. (2016). Dark Matters: Metaphorical Black Holes That Affect Ethnic Underrepresentation in Engineering. Paper Presented at the 126th ASEE Conference.

Vasquez, J. A. (1998). The Power of Power Politics: From Classical Realism to Neotraditionalism. Cambridge University Press.

Weick, K. E. (1979). The Social Psychology of Organizing. McGraw-Hill.

Yasin, A., \& Abu Zant, M. (2018). Detecting and Isolating Black-Hole Attacks in MANET Using Timer Based Baited Technique. Wireless Communications and Mobile Computing, (1)1, 1-10.

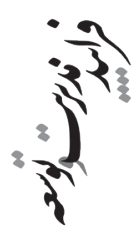

